Article

\title{
Scenario-Based Impacts of Land Use and Climate Change on Land and Water Degradation from the Meso to Regional Scale
}

\section{Aymar Y. Bossa ${ }^{1,2, *}$, Bernd Diekkrüger ${ }^{2}$ and Euloge K. Agbossou ${ }^{3}$}

1 West African Science Service Center on Climate Change and Adapted Land Use-WASCAL, Ouagadougou 06 P.O. Box 9507, Burkina Faso

2 Department of Geography, University of Bonn, Meckenheimer Allee 166, Bonn 53115, Germany; E-Mail: b.diekkrueger@uni-bonn.de

3 Faculty of Agricultural Sciences, University of Abomey-Calavi, Cotonou 01 BP. 526, Benin; E-Mail: agbossou.euloge@yahoo.fr

* Author to whom correspondence should be addressed; E-Mail: bossa.a@wascal.org; Tel.: +226-5037-5423.

External Editor: Julia Piantadosi

Received: 17 May 2014; in revised form: 16 September 2014 / Accepted: 8 October 2014 / Published: 20 October 2014

\begin{abstract}
Scale-dependent parameter models were developed and nested to the Soil and Water Assessment Tool-SWAT to simulate climate and land use change impacts on water-sediment-nutrient yields in Benin at a regional scale $\left(49,256 \mathrm{~km}^{2}\right)$. Weighted contributions of relevant landscape attributes characterizing the spatial pattern of ongoing hydrological processes were used to constrain the model parameters to acceptable physical meanings. Climate change projections (describing a rainfall reduction of up to $25 \%$ ) simulated throughout the Regional Model-REMO, very sensitive to a prescribed degradation of land cover, were considered. Land use change scenarios in which the population growth was translated into a specific demand for settlements and croplands (cropland increase of up to 40\%) according to the development of the national framework, were also considered. The results were consistent with simulations performed at the meso-scale $\left(586 \mathrm{~km}^{2}\right)$ where local management operations were incorporated. Surface runoff, groundwater flow, sediment and organic $\mathrm{N}$ and $\mathrm{P}$ yields were affected by land use change (as major effects) of $-8 \%$ to $+50 \%$, while water yield and evapotranspiration were dominantly affected by climate change of $-31 \%$ to $+2 \%$. This tendency was more marked
\end{abstract}


at the regional scale as response to higher scale-dependent rates of natural vegetations with higher conversions to croplands.

Keywords: SWAT; scaling; regionalization; nutrient loss; climate change; land use change

\section{Introduction}

Unsustainable land use is driving land degradation, which in the form of soil erosion, nutrient depletion, water scarcity, salinity and disruption of biological cycles is a fundamental and persistent problem, diminishing productivity, biodiversity, other ecosystem services, and contributing to climate change [1]. A global survey suggests that $40 \%$ of agricultural land is already degraded to the point that yields are greatly reduced, and a further $9 \%$ is degraded to the point that it cannot be reclaimed for productive use by farm level measures [2]. According to the Global Assessment of Human-induced Soil Degradation (GLASOD) [1,3,4] estimates, degradation of cropland appears to be most prevalent in Africa, affecting already in the 1990s 65\% of cropland areas, compared with 51\% in Latin America and $38 \%$ in Asia. Many studies have been conducted in parts of Africa to understand the processes as well as determinant and promoting causes, related to the specific climatological, meteorological and soil conditions [5-16], and have been capitalized into this current work.

Vulnerability to change, whether climate-induced or related to anthropogenic-induced changes in land use/land cover, is a major threat, consisting at the same time of a water dimension (reduced water availability), an agrarian dimension (falling yields) and an environmental dimension (weakening of the soil and increasing erosion) [7]. Several investigations on the global change processes and its impact on the hydrological cycle $[9,17-26]$ have shown that global climate change has a significant influence on the regional water and soil resources. Neumann et al. [23] investigated climate trends of temperature, precipitation and river discharge in the Volta Basin (West Africa) and have concluded on weak trends towards a decrease in rainfall with no clear trend on discharge as the anthropogenic influences (e.g., building of dams, intensified irrigation) were not quantified. Legesse et al. [21] evaluated the hydrological response of a catchment to climate and land use changes in Tropical Africa and found that a $10 \%$ decrease in rainfall produced a $30 \%$ reduction on the simulated hydrologic response of the catchment, while a $1.5^{\circ} \mathrm{C}$ increase in air temperature would result in a decrease in the simulated discharge of about 15\%. Moreover, they indicated that a conversion of the present day dominantly cultivated/grazing land by woodland would decrease the discharge at the outlet by about $8 \%$. Chaplot [20] examined the effects of increasing $\mathrm{CO}_{2}$ concentrations and rainfall changes associated with changes in average daily rainfall intensity, and surface air temperature on loads of water, $\mathrm{NO}_{3}-\mathrm{N}$ and sediments from watersheds exhibiting different environmental conditions. He found over a 100-year simulated period: (1) flow and sediment discharges affected by precipitation changes while temperature and changes in atmospheric $\mathrm{CO}_{2}$ concentration had a smaller effect; (2) $\mathrm{CO}_{2}$ concentration was the main controlling factor of $\mathrm{NO}_{3}-\mathrm{N}$ loads; and (3) global changes in the humid watershed had a greater effect on the water and soil resources. Ward et al. [25] evaluated the impact of land use and climate change on future suspended sediment yields and found an increase in all simulations due to conversion of forest to agricultural land. Conjoint sensitivity analyses have shown that although land 
use change acts as the primary control on long-term changes in sediment yield, the sensitivity of sediment yield to changes in climate increases as the percentage of deforested land increases. Mahe et al. [24] modeled the impact of land use change on soil water holding capacity and river flow in West Africa and found that the total reduction in water holding capacity is estimated to range from $33 \%$ to $62 \%$ between 1965 and 1995 . This was explained by the decline in the extent of natural vegetation from $43 \%$ to $13 \%$ of the total basin area, whilst the cultivated areas increased from $53 \%$ to $76 \%$ and the area of bare soil nearly tripled from $4 \%$ to $11 \%$. Li et al. [22] modeled the hydrological impact of land use change (West Africa) and pointed out that total deforestation (clearcutting) increases the simulated runoff ratio from 0.15 to 0.44 , and the annual streamflow by $35 \%-65 \%$, depending on location in the basin, although forests occupy only a small portion $(<5 \%)$ of the total basin area. They mentioned that there is no significant impact on the water yield and river discharge when the deforestation (thinning) percentage is below $50 \%$ or the overgrazing percentage below $70 \%$ for savanna and $80 \%$ for grassland areas; however, the water yield is increased dramatically when land cover change exceeds these thresholds. Faramarzi et al. [19] modeled the impacts of climate change on freshwater availability in Africa and the results indicated that the mean total quantity of water resources is likely to increase, but for individual catchments and countries, variations are substantial. Cornelissen et al. [18] assessed the suitability of different hydrological model types for simulating scenarios of future discharge behavior in West Africa in the context of climate and land use change. They found that all models simulate an increase in surface runoff due to land use change. The application of climate change scenarios resulted in considerable variation between the models and points not only to uncertainties in climate change scenarios. The conclusions drawn out from the above-presented studies are concordant with the different methodologies rolled out. They demonstrated significant sensitivities of soil and water resources to increase $\mathrm{CO}_{2}$, temperature, rainfall and land use depending on the study locations, the catchment characteristics, the modeling approaches, the land use change drivers, the structure of the atmosphere-ocean global climate models as well as the regional climate models behind the climate projections used. None of them has addressed the chemical dimension of soil degradation, notably the soil organic $\mathrm{N}$ and $\mathrm{P}$ loads and delivered together with sediment at catchment outlet. Organic $\mathrm{N}$ and $\mathrm{P}$ loads highly depend on landscape heterogeneity and spatial patterns of hydrological processes which are well known to smooth out with increasing catchment size resulting in more uncertain model parameters (without physical meaning) and more uncertain impact calculations at large scale, but almost none of the available impact studies have addressed this scaling problem, what is also offered in the present study.

It is widely accepted that the complexity of hydrological processes as well as land and water degradation depend on the environmental heterogeneity such as soil pattern, topography, geology, vegetation and anthropogenic impacts. Thus, the process-dependent hierarchization of landscape elements from local to regional scales [27] is recently reflected in the development of several computationally efficient conceptual and distributed physical-based models (e.g., SWAT), attempting to quantify the hydrological variability occurring at a range of scales. Therefore, catchments may be subdivided into a number of smaller units such as sub-catchments, hillslopes, hydrological response units, contour-based elements, and square grid elements [6,28-31], but opened discussions on the modeling uncertainty issue, including scaling-effects in model internal aggregation [32,33] for large scale applications. This often affects the magnitudes of model parameters which may finally have no 
consistent physical meanings, carrying too poor information [33]. A scale dependent parameterization approach may significantly reduce these sources of uncertainty and the problem of lack or non-accurate measurement data (e.g., stream water-sediment-nutrient measurements) at large catchment scale. This is crucial and of high interest for impact assessment of climate and land use change at large-scale in a data-poor environment like Benin.

Previous integrated modeling works in West Africa and in the upper Ouémé catchment of roughly $15,000 \mathrm{~km}^{2}$ in size in Benin $[9,16]$, have largely contributed to improving knowledge of recent land degradation processes from local to regional scales. The results have shown that amongst others silt and clay particle loads totaling 0.5 ton $\mathrm{ha}^{-1} \mathrm{a}^{-1}$ with an associated organic nitrogen load of $0.8 \mathrm{~kg} \cdot \mathrm{ha}^{-1} \mathrm{a}^{-1}[16]$. These results clearly indicate that the study area is impacted by land and water degradation processes, primary seen as human-induced or natural processes that negatively affect ecosystem as for resources storing and recycling. Scenario-based land use and climate change [34-37] may impact the degradation process to a level of $+50 \%$ of the observations $[15,16]$. The current work attempts to expand all above-mentioned dimensions of erosion-related degradation under different land use and climate scenarios to large catchment scales (up to 49,256 $\mathrm{km}^{2}$ ), while minimizing biases due to scaling-up processes such as model internal aggregation processes in the SWAT model. These thorough modeling exercises are still challenging the world scientific community and have never been parts of previous studies in Benin, as transferability of results through spatial scales stays an important underlying question.

This study aims to investigate how global change impacts on water/land degradation at different spatial scales in Benin. It specifically means to investigate the degradation trends at different catchment scales: (1) a meso-scale catchment $\left(586 \mathrm{~km}^{2}\right)$ investigation incorporating local-scale farming practices [16]; and (2) a large-scale $\left(49,256 \mathrm{~km}^{2}\right)$ investigation based on a regionalized model parameterization [38] based on scale-dependent model parameters for simulating water-sediment-nutrient fluxes. This latter approach makes use of physical catchment properties depending on the spatial scale as explanatory variables for model parameters using regression techniques.

\section{Materials and Methods}

\subsection{Study Area}

Located at about $90 \%$ in the Republic of Benin between $6^{\circ} 48^{\prime}$ and $10^{\circ} 12^{\prime} \mathrm{N}$ of latitude and as part of the stable margin of the West African Craton, the Ouémé catchment (49,256 $\mathrm{km}^{2}$, cf. Figure 1) is mainly characterized by a Precambrian basement, consists predominantly of complex migmatites granulites and gneisses, including less abundant mica shists, quarzites and amphibolites [9]. Syn-and post-tectonic intrusions of mainly granites, diorites, gabbros and volcanic rocks are present [39]. With a topographic relief generally low (highest elevation point of 617 meter) the land surface is slightly ondulating (granitic-gneissic plateau), strongly fractured (granitic peneplain) with typical seasonally waterlogged linear depressions (inland valleys) [9].

At a regional scale, fersialitic soils (ferruginous tropical sols) are predominant, characterized by clay translocation and iron segregation (ferruginous tropical sols with iron segregation), which lead to a clear horizon differentiation [40]. A local scale description has shown a typical catena with 
lixisols/acrisols on the upper and middle slopes, following by plinthosols on the downslopes, gleysols in the inland valleys and fluvisols on the fluvial plain [41].

Situated in a wet (Guinean coast) and a dry (Northern Soudanian zone) tropical climate, the Ouémé catchment records annual mean temperatures of $26{ }^{\circ} \mathrm{C}$ to $30{ }^{\circ} \mathrm{C}$, annual mean rainfalls of $1280 \mathrm{~mm}$ (from 1950 to 1969) and $1150 \mathrm{~mm}$ (from 1970 to 2004) at a climatic station close to $9^{\circ} \mathrm{N}$ latitude [9]. As shown in the Figure 1, the Soudanian zone has a unimodal rainfall season that peaks in August whereas the Guinean zone exhibits a bimodal rainfall season that peaks in June and October.

Figure 1. Location and climate condition of the study area, after Speth et al. [9]. The investigated catchments are Donga-Pont $\left(586 \mathrm{~km}^{2}\right)$, Vossa $\left(1935 \mathrm{~km}^{2}\right)$, Térou-Igbomakoro $\left(2344 \mathrm{~km}^{2}\right)$, Zou-Atchérigbé $\left(6978 \mathrm{~km}^{2}\right)$, Kaboua $\left(9459 \mathrm{~km}^{2}\right)$, Bétérou $\left(10,072 \mathrm{~km}^{2}\right)$, Savè $\left(23,488 \mathrm{~km}^{2}\right)$, Ouémé-Bonou $\left(49,256 \mathrm{~km}^{2}\right)$.
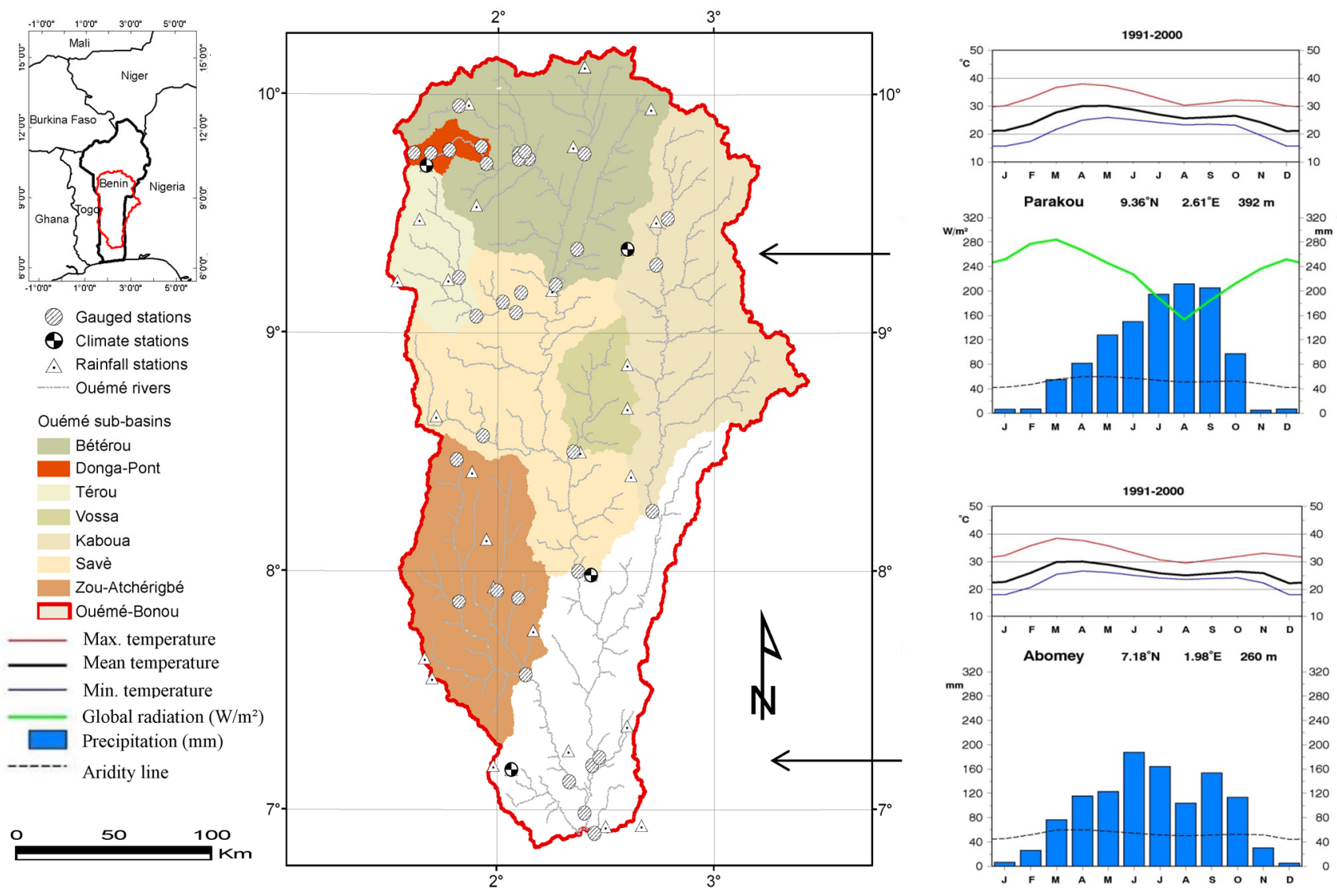

The catchment landscape is characterized by forest islands, gallery forest, savannah, woodlands, agricultural lands and pastures. Agriculture and other human activities have led to large-scale deforestation and fragmentations leaving only small relicts of the natural vegetation types within a matrix of degraded secondary habitats [9].

With a length of about $510 \mathrm{~km}$ and with two most important tributaries, Zou $(150 \mathrm{~km})$ and Okpara $(200 \mathrm{~km})$, the Ouémé river drains into Lake Nokoué $\left(150 \mathrm{~km}^{2}\right)$ and flows through the coastal lagoon system into the sea. Rainfall-runoff variability is high in the catchment, leading to runoff coefficients varying from 0.10 to 0.26 (of the total annual rainfall), with the lowest values for the savannahs and forest landscapes [9]. 


\subsection{Modeling Approach}

The SWAT (Soil and Water Assessment Tool) model is an eco-hydrological model developed by the United States Department of Agricultural-Research-Service (USDA-ARS) [31]. It is a continuoustime model that operates at a daily time-step. It allows the assessment of various subsurface flows and storages and related sediment and nutrient loads, taking into account the feedback between plant growth, water, and nutrient cycle, and helps to understand land management practice effects on water, sediment, and nutrient dynamics. It is a catchment scale model which can be applied from small $\left(\mathrm{km}^{2}\right)$ to regional $\left(100,000 \mathrm{~km}^{2}\right)$ scale. SWAT subdivides the catchment into sub-catchments based on a Digital Elevation Model (DEM). Each sub-catchment consists of a number of Hydrological Response Units (HRUs) which are homogeneous concerning soil, relief, and vegetation. The HRUs are not georeferenced and not linked to each other within the sub-catchment.

In SWAT surface runoff is simulated using a modified version of the SCS CN method [42]. Lateral flow is simulated using the kinematic method of Sloan and Moore [43]. Percolation occurs when the soil field capacity is exceeded, recharging two aquifer systems: an unconfined aquifer generating base flow to the catchment streams, and a confined (deep) aquifer generating base flow to streams outside the catchment. The mass of nitrate lost from the soil horizons is determined using the nitrate concentration in the mobile water multiplied by the water volume flowing in each pathway. Rainfallrunoff erosion is estimated using the Modified Universal Soil Loss Equation (MUSLE) [44]. Organic $\mathrm{N}$ attached to sediments is estimated based on the loading function of McElroy et al. [45] and modified by Williams and Hann [46] to consider each runoff events. The model computes evaporation from soils according to Ritchie [47]. Actual soil water evaporation is estimated using exponential functions of soil depth and water content. Plant transpiration is computed as a linear function of potential evapotranspiration and leaf area index.

The overall modeling approach is summarized in Figure 2, showing the nature and source of the different data layers, their scales and types of parameters and investigations $[48,49]$, in the structure as required for applying the SWAT model. A $90 \mathrm{~m}$ resolution Digital Elevation Model from the Shuttle Radar Topography Mission-SRTM was used. A SOil and TERrain (SOTER) digital database established at the scale 1:200.000 for the whole Ouémé catchment, in corporation with INRAB (Institut National de la Recherche Agricole du Bénin) is considered in this study (cf. Bossa et al. [50] for more details and an overview of the map and soil properties). This database includes different soil properties that were determinant for the model setup and parameterization: saturated hydraulic conductivity, organic CNP, bulk density, texture, erodibility factor, available water content, hydrology group, etc. The land use/cover map considered in this study has been established at $250 \mathrm{~m}$ resolution from 3 scenes satellite images LANDSAT ETM+ of 2003 [37] with an overall accuracy of $87 \%$. More than 650 observation points were checked during the ground checks and 17 land use/cover classes were defined. Agricultural calendars depending on rainy season onsets, rainfall rhythms, and crop growth cycles/management over the period 2004-2009 (activity reports from the Regional Center of Agricultural Promotion-CeRPA and Ministry of Agriculture, Livestock and Fisheries-MAEP) have been used for the baseline agricultural practices introduced in SWAT (cf. Tables 1 and 2 for an example). Climate data (rainfall, temperature, solar radiation, wind speed and air humidity) were 
collected from 35 stations managed by the German Research Project IMPETUS, IRD (Institut de Recherche pour le Développement, France), and DMN (Direction de la Météorologie Nationale).

Figure 2. Schematization of the modeling approach. Soil and land use data are from IMPETUS [48] and INRAB (Institut National de la Recherche Agricole du Bénin [49]), Climate data are from IMPETUS, IRD (Institut de Recherche pour le Développement, France), and DMN (Direction de la Météorologie Nationale), Geology data is from OBEMINES (Office Béninoise des MINES). CountryStat: Benin National Statistics (Food and Agriculture data network). CeRPA: Regional Center of Agricultural Promotion. MAEP: Ministry of Agriculture, Livestock and Fisheries. SSC means suspended sediment concentration.

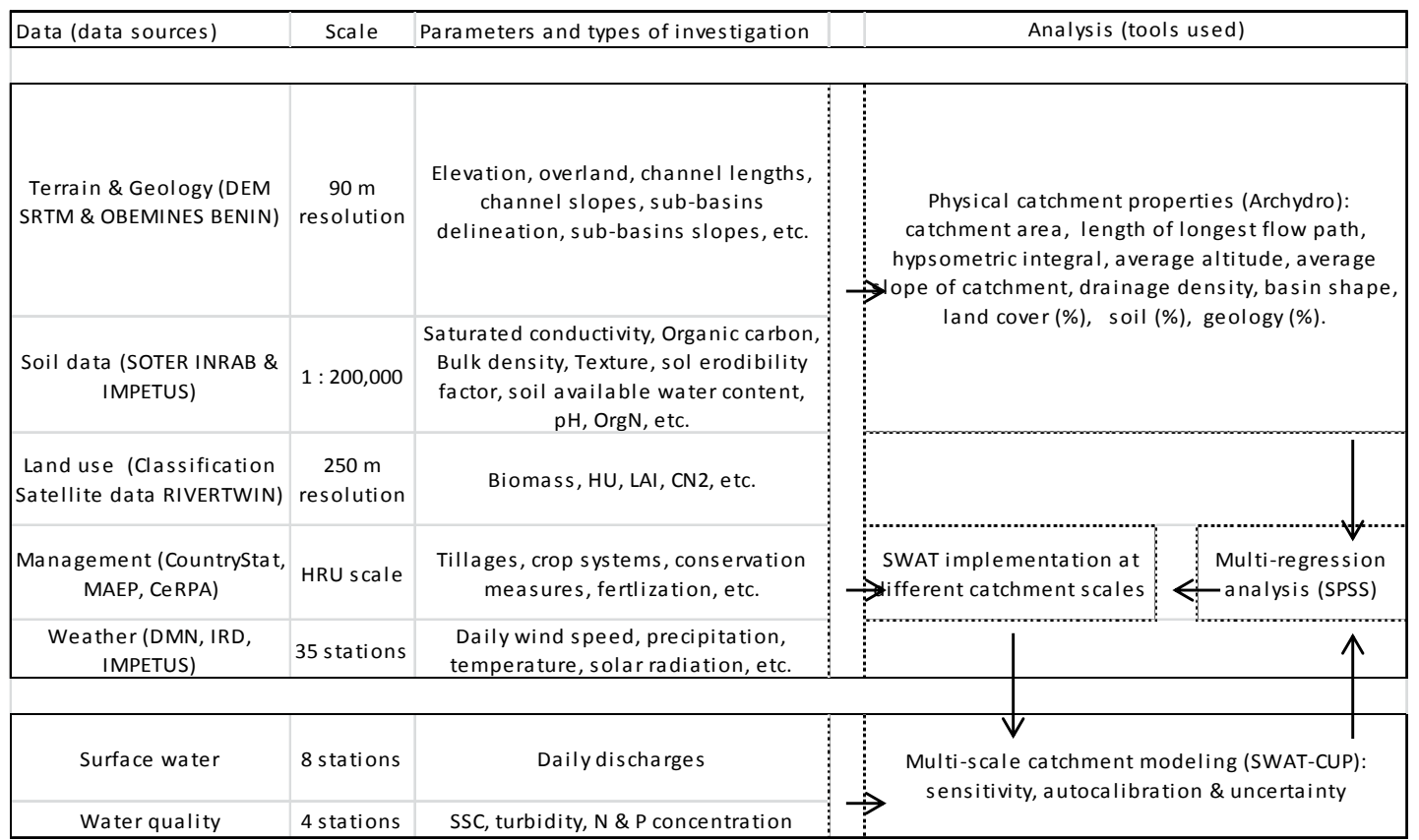

Table 1. Management operations considered for croplands in the Donga-Pont catchment. T1, T2 and T3: Tillage operation; F1 and F2: Fertilization.

\begin{tabular}{cccccc}
\hline Croplands & T1 & F1 & T2 & T3 & F2 \\
\hline Elemental N-P $\left(\mathrm{kg} \mathrm{ha}^{-1}\right)$ & & $10.5-6$ & & & \\
Elemental N $\left(\mathrm{kg} \mathrm{ha}^{-1}\right)$ & & & & & 10.5 \\
Tillage depth $(\mathrm{cm})$ & 25 & & 10 & 10 & \\
Mixing efficiency & 0.5 & & 0.25 & 0.25 & \\
\hline
\end{tabular}

Table 2. Management operations considered for pastures in the Donga-Pont catchment. $\mathrm{NH} 3 \mathrm{~N}$ is the dissolved nitrogen, easily convertible into nitrate.

\begin{tabular}{lc}
\hline Pastures & Grazing \\
\hline Grazing days & 300 \\
Biomass eaten: beef/dairy-sheep-goat $\left(\mathrm{kg} \mathrm{ha}^{-1} \mathrm{~d}^{-1}\right)$ & $76-24-28$ \\
Biomass trampled: beef/dairy-sheep-goat $\left(\mathrm{kg} \mathrm{ha}^{-1} \mathrm{~d}^{-1}\right)$ & $15-5-6$ \\
Manure beef $(1 \% \mathrm{~N}-0.4 \% \mathrm{P}-3 \% \mathrm{ORGN}-0.7 \% \mathrm{ORGP}-95 \% \mathrm{NH} 3 \mathrm{~N})\left(\mathrm{kg} \mathrm{ha}^{-1} \mathrm{~d}^{-1}\right)$ & 38 \\
Manure sheep $(1 \% \mathrm{~N}-0.4 \% \mathrm{P}-3 \% \mathrm{ORGN}-0.7 \% \mathrm{ORGP}-95 \% \mathrm{NH} 3 \mathrm{~N})\left(\mathrm{kg} \mathrm{ha}^{-1} \mathrm{~d}^{-1}\right)$ & 12 \\
Manure goat $(1 \% \mathrm{~N}-0.4 \% \mathrm{P}-3 \% \mathrm{ORGN}-0.7 \% \mathrm{ORGP}-95 \% \mathrm{NH} 3 \mathrm{~N})\left(\mathrm{kg} \mathrm{ha}^{-1} \mathrm{~d}^{-1}\right)$ & 64 \\
\hline
\end{tabular}


Besides discharge data continuously available for more or less 10 years (1998-2008) at 8 gauging stations, water samples (9 liters per day) were collected in 2004, 2005, 2008, 2009 and 2010 at 4 gauging stations (Donga-Pont, Bétérou, Térou and Zou-Atchérigbé, cf. Figure 1) and filtered in order to calculate daily suspended sediment concentration. Multi-parameter probes YSI 600 OMS (including one turbidity-broom sensor YSI 6136) were installed at the same stations to register turbidity at a high temporal resolution (used to calculate continuous time series of suspended sediment concentrations) to consider the hysteresis effects on the relationship between sediment and discharge. After filtration the obtained sediments were analyzed in the laboratory for organic Nitrogen and non-soluble/organic Phosphorus content. Weekly water samples were collected (2008-2010) for analyzing Nitrate and soluble Phosphorus.

The general input data were used to compute selected physical catchment attributes and beyond six individual Ouémé sub-catchments (Donga-Pont, Térou, Bétérou, Zou-Atchérigbé, Vossa and Kaboua, cf. Figure 1) were considered for SWAT calibration. Multi-scale auto-calibration and uncertainty analysis were performed applying the SUFI-2 procedure (Sequential Uncertainty Fitting version 2, SWAT-CUP interface [51]) so discharge, sediment, nitrate and organic N and P were simultaneously calibrated. SPSS software was used to statistically analyze two different matrixes of calibrated parameter sets and computed catchment attributes. A correlation analysis was performed to identify physical catchment attributes meaningful for each calibrated model parameter. Multiple regression analyses were later on performed to establish the regionalization rules which are in fact assumed to highly capture the catchment heterogeneity as well as the spatial pattern of the hydrological processes. Table 3 shows the calibration and validation periods as well as quality measures of the simulations for the different sub-catchments investigated.

Table 3. Model goodness of fit to measurements for the different sub-catchments involved in the multiple regression analysis, for model calibration. Information concerning validation are provided in brackets.

\begin{tabular}{|c|c|c|c|c|c|c|c|}
\hline & & Donga & Vossa & Térou & Atchérigbé & Kaboua & Bétérou \\
\hline \multirow{4}{*}{ Discharge } & Doriod & 2006-2008 & 1998-2000 & $2002-2005$ & $2007-2008$ & 2004-2006 & 2006-2009 \\
\hline & 1. & $(1998-2005)$ & (1995) & $(1998-2001,2006)$ & $(2001-2006,2009)$ & (1995-1998) & (1998-2005) \\
\hline & $\mathrm{R}^{2}$ & $0.72(0.58)$ & $0.75(0.63)$ & $0.75(0.61)$ & $0.89(0.71)$ & $0.73(0.55)$ & $0.75(0.64)$ \\
\hline & NS & $0.72(0.51)$ & $0.75(0.34)$ & $0.74(0.51)$ & $0.82(0.62)$ & $0.67(0.40)$ & $0.60(0.59)$ \\
\hline \multirow{4}{*}{ Sediment } & riod & 2008 & - & 2004-2005 & 2008 & - & 2008-2009 \\
\hline & renod & $(2005)$ & - & (2006) & (2009) & - & (2004-2005) \\
\hline & $\mathrm{R}^{2}$ & $0.69(0.58)$ & - & $0.44(0.33)$ & $0.66(0.67)$ & - & $0.43(0.27)$ \\
\hline & NS & $0.67(0.55)$ & - & $0.41(0.32)$ & $0.64(0.67)$ & - & $0.30(0.14)$ \\
\hline \multirow{4}{*}{ Nitrate } & Doris & 2008 & - & - & 2008 & - & 2008-2009 \\
\hline & 1 the & (2008-2009) & - & - & (2009) & - & $(2008)$ \\
\hline & $\mathrm{R}^{2}$ & $0.99(0.95)$ & - & - & $0.86(0.62)$ & - & $0.73(0.52)$ \\
\hline & NS & $0.99(0.78)$ & - & - & $0.81(0.54)$ & - & $(0.46)$ \\
\hline
\end{tabular}

Regarding discharge simulations, poor model efficiency were obtained for validation in Vossa and Kaboua sub-catchments ( 0.34 and 0.40 respectively) due mainly to peak overestimation caused partly by land use map derived from 2003 Landsat images, which considered more agricultural areas than the 
reality of the validation period (1995-1998). Critical model performances were obtained for sediment simulation in the Bétérou sub-catchments, where the model efficiency decreased even to 0.14 . This may be mainly caused by strong hysteresis effects observed at this station, which was not equipped of turbidity probe as used at the Donga-Pont and Atchérigbé gauging stations to minimize this effect. Nitrate load was in general well represented in the model with coefficients of determination ranging from 0.62 to 0.99 and model efficiencies ranging from 0.54 to 0.99 . Higher performances were observed for smaller sub-catchments. Calibrated model parameters are presented in Table 4 for all investigated sub-catchments.

Table 4. Calibrated model parameter matrix involved in the multiple regression analysis. The letters v, $r$ and a mean values, relative change and absolute change, respectively. CN2: SCS Curve Number, ALPHA_BF: base flow recession constant; SOL_K: soil hydraulic conductivity, RCHRG_DP: aquifer percolation coefficient, GWQMN: minimum water level for base flow generation, REVAPMN: threshold water level in a shallow aquifer for capillary rise, ESCO: Soil evaporation compensation factor, GW_DELAY: groundwater delay, Ch_K2: Effective channel hydraulic conductivity, USLE_P: Practice factor, USLE_K: Soil erodibility factor, SPEXP: Exponent for calculating max sediment retrained, SURLAG: Surface runoff lag coefficient, NPERCO: Nitrate percolation coefficient.

\begin{tabular}{|c|c|c|c|c|c|c|c|}
\hline Parameter & Description & Donga & Vossa & Térou & Atchérigbé & Kaboua & Bétérou \\
\hline $\operatorname{ESCO}(v)$ & Soil evaporation compensation factor (-) & 0.38 & 0.28 & 0.49 & 0.35 & 0.28 & 0.43 \\
\hline SOL_Z (r) & Soil depth (mm) & 0.27 & 0.01 & 0.37 & 0.16 & 0.06 & 0.03 \\
\hline $\mathrm{CN} 2(\mathrm{r})$ & Curve Number $(-)$ & 6.65 & 3.86 & 5.55 & 6.24 & 3.97 & 2.51 \\
\hline GWQMN (v) & Threshold depth for ground water flow to occur (mm) & 38.75 & 7.50 & 47.50 & 28.50 & 30.50 & 43.50 \\
\hline REVAPMN (v) & Threshold water level in shallow aquifer for revap (mm) & 15.25 & 6.50 & 45.50 & 18.50 & 26.50 & 26.50 \\
\hline $\mathrm{Ch}$ K2 $2(\mathrm{v})$ & Effective channel hydraulic conductivity $(\mathrm{mm} / \mathrm{hr})$ & 3.95 & 1.00 & 12.77 & 10.65 & 1.00 & 12.52 \\
\hline Sol_K (r) & Saturated hydraulic conductivity $(\mathrm{mm} / \mathrm{hr})$ & -0.78 & -0.65 & -0.73 & -0.35 & -0.82 & -0.66 \\
\hline GW_DELAY (v) & Ground water delay ( day) & 15.08 & 17.12 & 23.25 & 10.87 & 16.04 & 24.80 \\
\hline USLE_P (v) & Practice factor $(-)$ & 0.13 & 0.10 & 0.07 & 0.15 & 0.18 & 0.00 \\
\hline USLE_K (r) & Soil erodibility factor $\left(0.013 \mathrm{t} \mathrm{m}^{2} \mathrm{~h} /\left(\mathrm{m}^{3} \mathrm{t} \mathrm{cm}\right)\right)$ & 0.03 & 0.16 & 0.08 & 0.14 & 0.25 & -0.57 \\
\hline $\operatorname{SPEXP}(v)$ & Exponent for calculating max sediment retrained (-) & 1.35 & 1.07 & 1.21 & 1.20 & 1.28 & 1.38 \\
\hline SURLAG (v) & Surface runoff lag coefficient $(-)$ & 0.19 & 0.35 & 0.24 & 0.25 & 0.17 & 0.10 \\
\hline ALPHA_BF (v) & Base flow recession factor ( day) & 0.06 & 0.17 & 0.07 & 0.12 & 0.11 & 0.15 \\
\hline NPERCO (v) & Nitrate percolation coefficient (-) & 0.49 & 0.88 & 0.74 & 0.71 & 0.32 & 0.67 \\
\hline RCHRG DP (v) & Fraction of deep aquifer percolation $(-)$ & 0.25 & 0.20 & 0.17 & 0.22 & 0.15 & 0.29 \\
\hline
\end{tabular}

In the following paragraphs of this section, details of the calibration and validation issues are presented as follows for the Atchérigbé sub-catchment $\left(6978 \mathrm{~km}^{2}\right)$ to provide a complete overview on the measurements involved into the multi-scale modeling step. The validation of the regionalization rules is presented for the Savè sub-catchment $\left(23,488 \mathrm{~km}^{2}\right)$ in this same section and we should highlight that orders of magnitude of impacts of climate and land use change scenarios are presented and compared for the two targeted spatial scales (Donga-Pont: $586 \mathrm{~km}^{2}$ and Ouémé-Bonou: 49,256 km²) in the result section.

Simulated versus observed daily water discharge and sediment yield are shown in Figures 3 and 4 for the Atchérigbé sub-catchment (cf. Figure 1). Recession periods were generally well represented. 
Less accurate predictions of single peaks are also shown in some years, partly due to the measurement errors during exceptional flooding years (2003 and 2007) in which over bank full discharge was observed at the gauging station. Differences are also usually caused by the SWAT structure, since it is a continuous time model with a daily time step and sub-scale processes such as single-event flood routing cannot be efficiently predicted. In addition, the daily measured precipitation for $24 \mathrm{~h}$ starts at 6:00 am and may not well match to the daily average discharge values, which were measured for $24 \mathrm{~h}$ from midnight on [52]. As it can be seen from the figures in the year 2008, discharge measurement gaps of even more than 10 days can happen due mainly to technical problems.

Figure 3. Simulated vs. observed daily discharge for the Atchérigbé sub-catchment $\left(6978 \mathrm{~km}^{2}\right)$. Calibration period was 2007 to $2008\left(\mathrm{R}^{2}=0.89\right.$ and $\left.\mathrm{ME}=0.83\right)$, validation period was 2001-2006, and $2009\left(\mathrm{R}^{2}=0.71\right.$ and $\left.\mathrm{ME}=0.62\right)$.

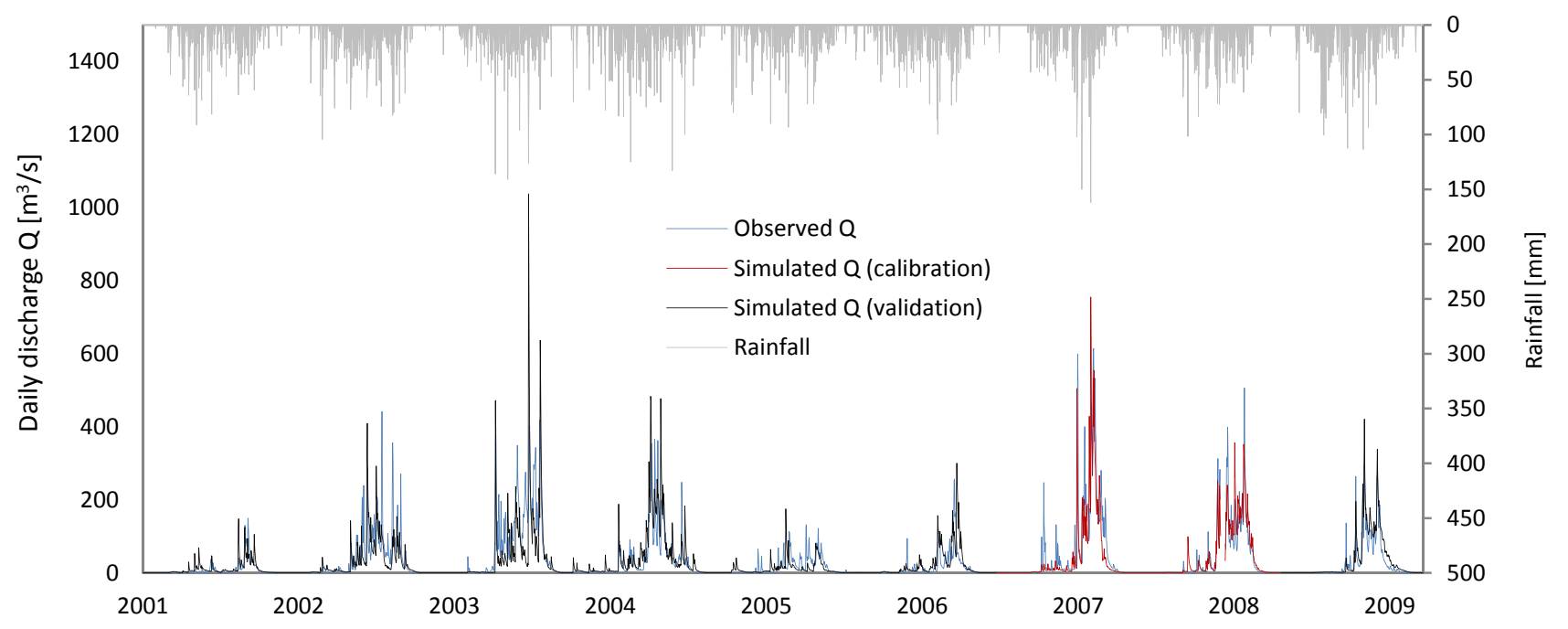

Figure 4. Simulated vs. Observed daily sediment yield for Atchérigbé sub-catchment $\left(6978 \mathrm{~km}^{2}\right)$. Calibration period was $2008\left(\mathrm{R}^{2}=0.66\right.$ and $\left.\mathrm{ME}=0.64\right)$, validation period was $2009\left(\mathrm{R}^{2}=0.67\right.$ and $\left.\mathrm{ME}=0.67\right) . \mathrm{SSC}=$ suspended sediment.

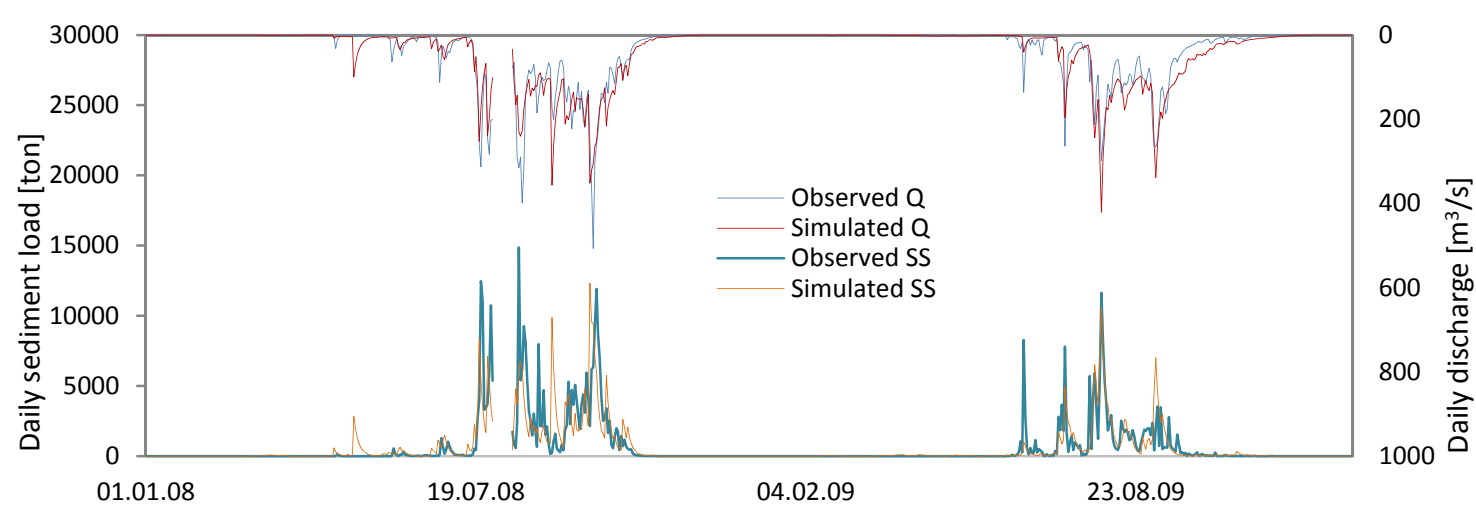

Simulated versus observed daily stream water nitrate load are shown in Figure 5 for the same Atchérigbé sub-catchment. Similarly to the sediment yield, nitrate peaks accompanied discharge peaks mainly caused by combined effects of increase nitrate loading and increase in water volume. Due to the sampling time scale (one time a week) several peaks were missed, but did not affect the model calibration. 
According to FAO [53], water degradation by sediment has a chemical dimension - the silt and clay fraction, primary carrier of adsorbed chemicals, like nitrogen and phosphorus, which are transported by sediment into the aquatic system. Figure 6 shows weekly simulated versus observed organic $\mathrm{N}$ and $\mathrm{P}$ delivery at the Atchérigbé gauging station. Organic $\mathrm{N}$ and $\mathrm{P}$ were not calibrated. Since it was assumed that a good adjustment of soil nutrient pools, nitrate and sediment loads would be reflected in their simulations, only a validation was performed. Model goodness-of-fit were acceptable: $0.58\left(\mathrm{R}^{2}\right)$ and 0.78 (NS) for organic Nitrogen and $0.89\left(\mathrm{R}^{2}\right)$ and $0.96(\mathrm{NS})$ for organic Phosphorus.

Figure 5. Simulated vs. observed daily nitrate load for Atchérigbé sub-catchment $\left(6978 \mathrm{~km}^{2}\right)$. Calibration period was $2008\left(\mathrm{R}^{2}=0.86\right.$ and $\left.\mathrm{ME}=0.81\right)$, validation period was $2009\left(\mathrm{R}^{2}=0.62\right.$ and $\left.\mathrm{ME}=0.54\right)$.

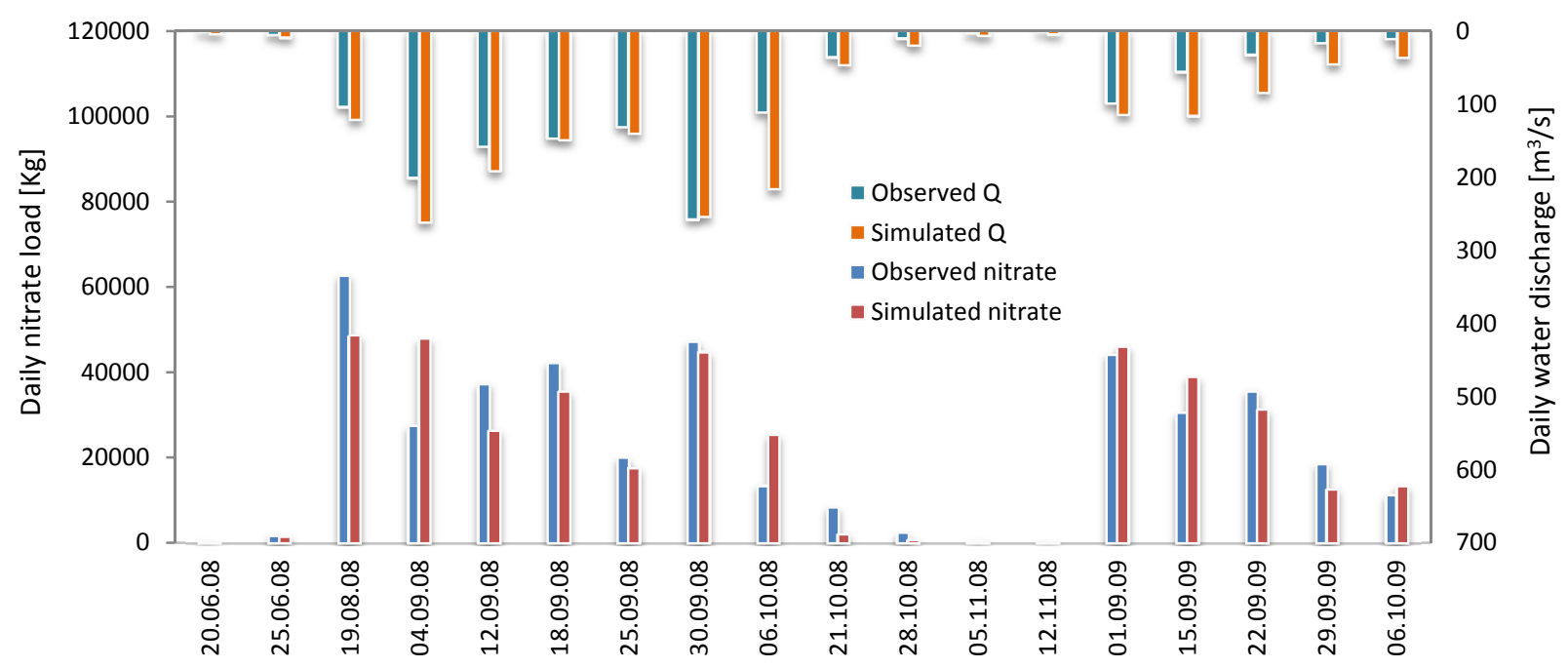

Figure 6. Simulated vs. observed weekly organic N and $\mathrm{P}$ load for the Atchérigbé sub-catchment $\left(6978 \mathrm{~km}^{2}\right)$. Only validation was performed from 2008 to 2009 with $\mathrm{R}^{2}=0.58$ and $\mathrm{ME}=0.78$ for organic Nitrogen and $\mathrm{R}^{2}=0.89$ and $\mathrm{ME}=0.96$ for organic Phosphorus.

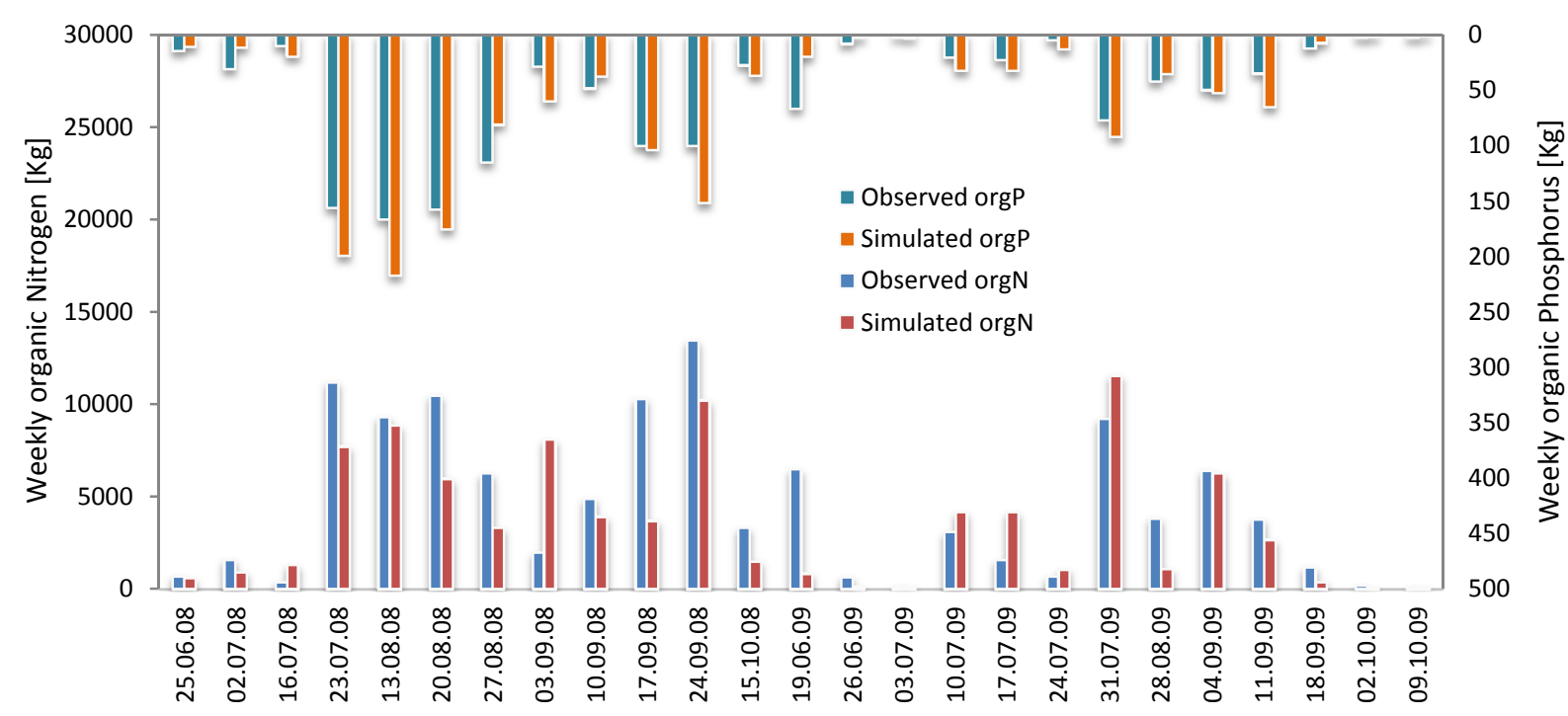


Table 5 shows the computed regionalization rules and derived parameter sets for the Savè $\left(23,488 \mathrm{~km}^{2}\right.$, cf. Figure 1) sub-catchment and Ouémé-Bonou $\left(49,256 \mathrm{~km}^{2}\right.$, cf. Figure 1) catchment. Physical catchment attributes depending on spatial scale were used as explanatory variables of SWAT model parameters. With respect to discharge, validation was performed for the Savè sub-catchment with a goodness-of-fit around 0.7 for model efficiency and $\mathrm{R}^{2}$ (Figure 7 ).

Table 5. Best regression-based parameter model and resulting values for three independent catchments (Savè: 23,488 km², Ouémé-Bonou: 49,256 km²). CN2: SCS Curve Number, ALPHA_BF: base flow recession constant; SOL_K: soil hydraulic conductivity, RCHRG_DP: aquifer percolation coefficient, GWQMN: minimum water level for base flow generation, REVAPMN: threshold water level in a shallow aquifer for capillary rise, ESCO: Soil evaporation compensation factor, GW_DELAY: groundwater delay, Ch_K2: Effective channel hydraulic conductivity $(\mathrm{mm} / \mathrm{h})$, USLE_P: Practice factor $(-)$, USLE_K: Soil erodibility factor $\left[0.013 \mathrm{t} \mathrm{m}^{2} \mathrm{~h} /\left(\mathrm{m}^{3} \mathrm{t} \mathrm{cm}\right)\right]$, SPEXP: Exponent for calculating max sediment retrained (-), SURLAG: Surface runoff lag coefficient (-), NPERCO: Nitrate percolation coefficient $(-)$.

\begin{tabular}{|c|c|c|c|c|}
\hline Parameters & Equations & $\mathbf{R}^{2}$ & Savè & Ouémé-Bonou \\
\hline ESCO & $=0.935-0.217($ Average slope of catchment $)+0.00327(\%$ Alterites $)$ & 0.92 & 0.34 & 0.37 \\
\hline SOL_Z & $=0.758-0.01(\%$ Migmatites $)$ & 0.81 & 0.02 & 0.08 \\
\hline SOL_K & $=26.991-0.278(\%$ Percentage of level $)$ & 0.92 & -0.58 & -0.76 \\
\hline $\mathrm{CN} 2$ & $=10.0-0.0824$ Migmatites $(\%)$ & 0.49 & 3.94 & 4.4 \\
\hline GWQMN & $=185-49.2($ Average slope of catchment $)-0.255(\%$ Migmatites $)$ & 0.85 & 26.89 & 37.28 \\
\hline REVAPMN & $=16.5+0.769(\%$ Alterites $)$ & 0.6 & 20.37 & 18.56 \\
\hline $\mathrm{Ch} \_\mathrm{K} 2$ & $=56.1-16.0($ Average slope of the catchment $)-0.461(\%$ Granites $)$ & 0.98 & 8.12 & 11.53 \\
\hline ALPHA_BF & $=-0.0794+0.00300(\%$ Migmatites $)$ & 0.87 & 0.14 & 0.12 \\
\hline GW_DELAY & $=19.0-0.248(\%$ Crop land $)+0.165(\%$ Savannah $)$ & 0.98 & 22.17 & 16.82 \\
\hline USLE_P & $=0.129-0.0143(\%$ Lateritic consolidated soil layer $)$ & 0.51 & 0.06 & 0.07 \\
\hline USLE_K & $=0.162-0.0848(\%$ Lateritic consolidated soil lay $)$ & 0.85 & -0.24 & -0.18 \\
\hline NPERCO & $\begin{array}{l}=1.72-3.80(\% \text { Hypsometric integral })+0.00779(\% \text { Circularity Index })- \\
0.033(\% \text { Elongation ratio })\end{array}$ & 0.85 & 0.08 & 0.47 \\
\hline RCHRG_DP & $=-0.758+0.462\left(\right.$ Drainage density $\left.\left(\mathrm{km} / \mathrm{km}^{2}\right)\right)$ & 0.55 & 0.24 & 0.99 \\
\hline SPEXP & $=1.47-0.00454$ Lixisol $(\%)+0.00011$ Migmatites $(\%)$ & 0.7 & 1.22 & 1.47 \\
\hline SURLAG & $=0.109+0.003$ Lixisol $(\%)-0.016$ Lateritic consolidated soil layers $(\%)$ & 0.93 & 0.19 & 0.22 \\
\hline
\end{tabular}

\subsection{Climate and Land Use Change Scenarios}

The climate scenarios used in this study were computed by Paeth et al. [36] for a part of Africa from $-15^{\circ} \mathrm{S}$ to $45^{\circ} \mathrm{N}$ latitude using the regional climate model REMO driven by the IPCC (Intergovernmental Panel on Climate Change) SRES (Special Report on Emission Scenarios) scenarios A1B and B1. The IPCC SRES scenario A1B characterizes a globalized world of rapid economic growth and comparatively low population growth. The SRES scenario B1 also characterizes a future globalized world with a low population growth. REMO is a regional climate model that is nested in the global circulation model ECHAM5/MPI-OM Paeth et al. [54]. REMO was forced on a grid of $50 \mathrm{~km}$ resolution throughout the first half of the 21 st century over West Africa. 
Figure 7. Observed vs. simulated total discharge (validation) using the regression-based parameters for the Savè catchment $\left(23,488 \mathrm{~km}^{2}\right)$, with 0.71 for $\mathrm{R}^{2}$ and 0.67 for model efficiency (ME). Savè was chosen for the validation because measurements at Ouémé-Bonou are not reliable.

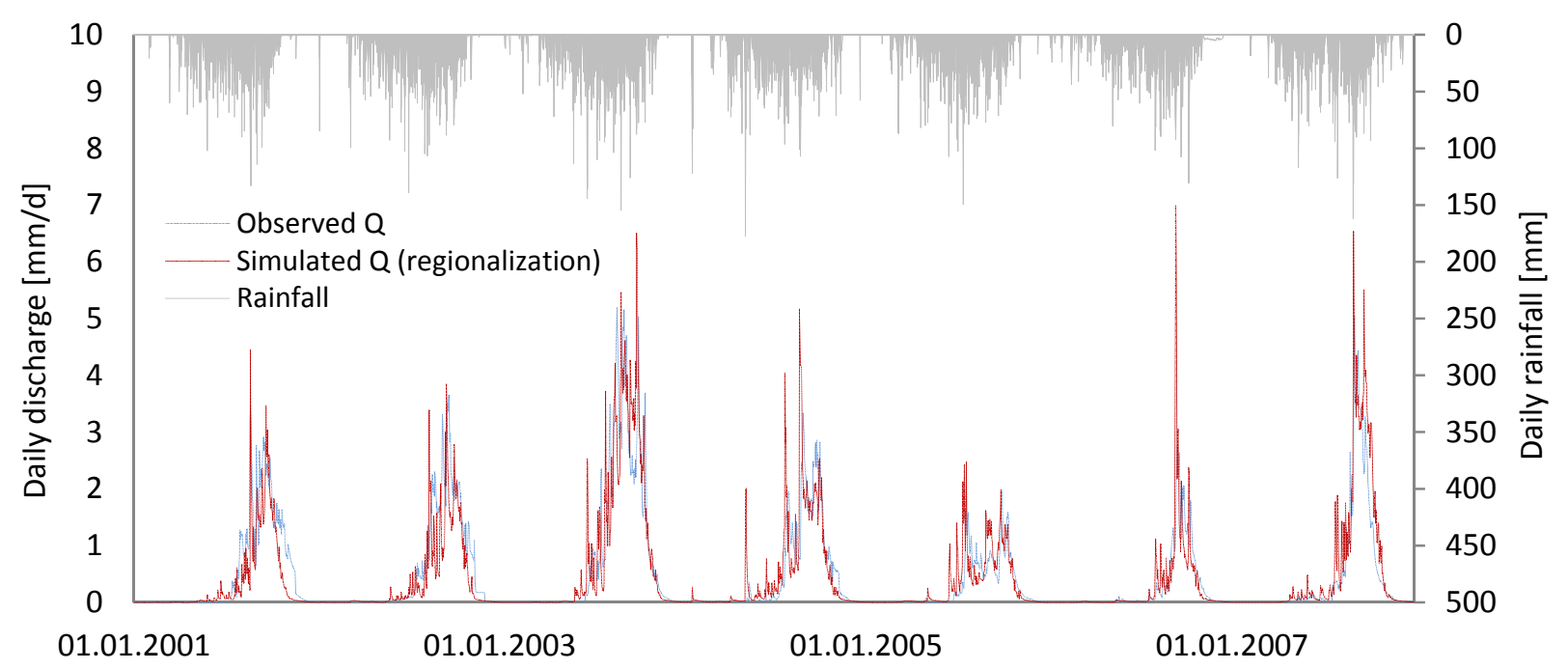

Initial runs of REMO over West Africa have shown systematically underestimated rainfall amounts and variability with a shift in the pattern towards more weak events and fewer extremes. This was addressed by applying the Model Output Statistics-MOS to correct monthly bias using other nearsurface parameters such as temperature, sea level pressure and wind. Since the regional-mean (precipitation) strongly differed from the observed spatial patterns of daily rainfall events, a conversion of the MOS-corrected regional-mean from REMO to local rainfall event patterns has been done. Virtual station data, matching the rainfall stations in Benin, were useful to adjust the results to the statistical characteristics of observed daily precipitation at the rainfall stations by probability matching.

Figure 8a shows mean monthly REMO rainfall amounts over 1960-2000 compared with measurements over 1998-2005 for the upper Ouémé catchment (14,500 km² including Donga-Pont $\left(586 \mathrm{~km}^{2}\right)$, Térou-Igbomakoro $\left(2344 \mathrm{~km}^{2}\right)$ and Bétérou $\left(10,072 \mathrm{~km}^{2}\right)$ ), while Figure $8 \mathrm{~b}$ presents mean monthly water discharges simulated with SWAT using REMO outputs over 1960-2000 compared with measurements over 1998-2005. These figures suggested that REMO and SWAT represent correctly the observations.

Climate change projections as simulated throughout REMO are very sensitive to a prescribed degradation of land cover. This sensitivity in addition to an increasing greenhouse gases concentrations have resulted in distinctly warmer and drier climates (with frequent droughts) for the investigated period 2000-2050 over West Africa, reductions in annual rainfall amounts of about $20 \%-25 \%$ of the 20th century annual amounts.

For the Ouémé-Bonou catchment REMO projects a decrease of annual rainfall between $9 \%$ and $12 \%$ for the scenario B1 and for the period 2010-2030. It increases of up to 4\% for the scenario A1B over the period 2010-2014, before decreasing of up to 14\% between 2015 and 2029. Maximum and minimum temperatures are expected to increase of up to $2.5^{\circ} \mathrm{C}$ over the next 40 years (Figure 9). 
Figure 8. (a) Mean monthly rainfall from REMO output (period 1960-2000) compared with measurements (period 1998-2005) for the upper Ouémé catchment [15]; (b) Simulated mean monthly water discharge with SWAT using REMO output (period 1960-2000) compared measurements (period 1998-2005) for the upper Ouémé catchment [15].
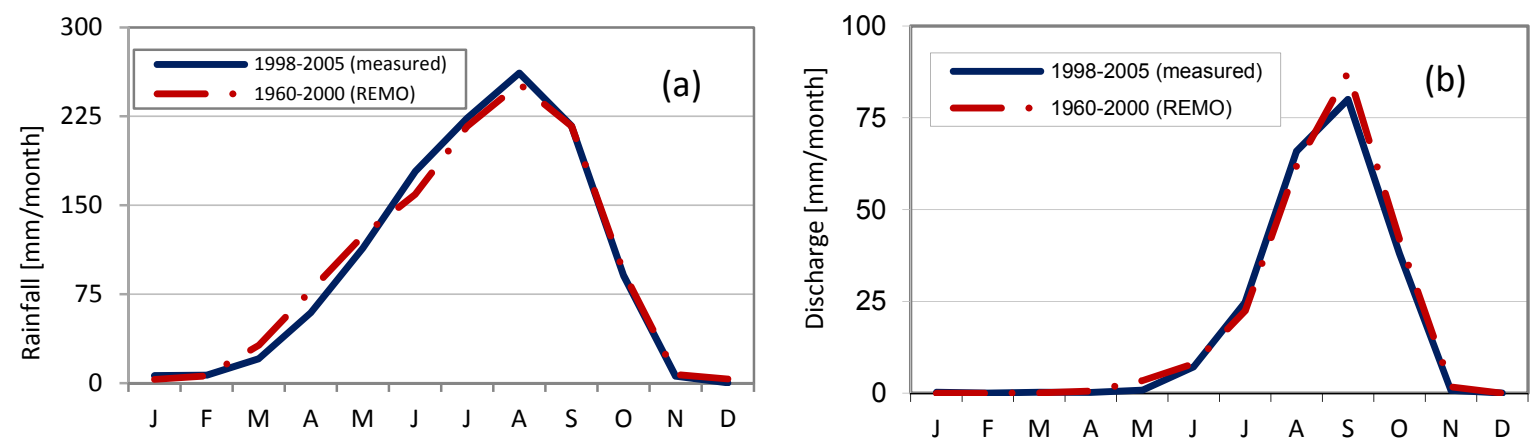

Figure 9. Projected changes in annual precipitation and near-surface temperatures until 2050 over tropical and northern Africa due to increasing greenhouse gas concentrations and man-made land cover changes [55]. The scenario A1B describes a globalized world of rapid economic growth and comparatively low population growth. The scenario B1 also characterizes a future globalized world with a low population growth.

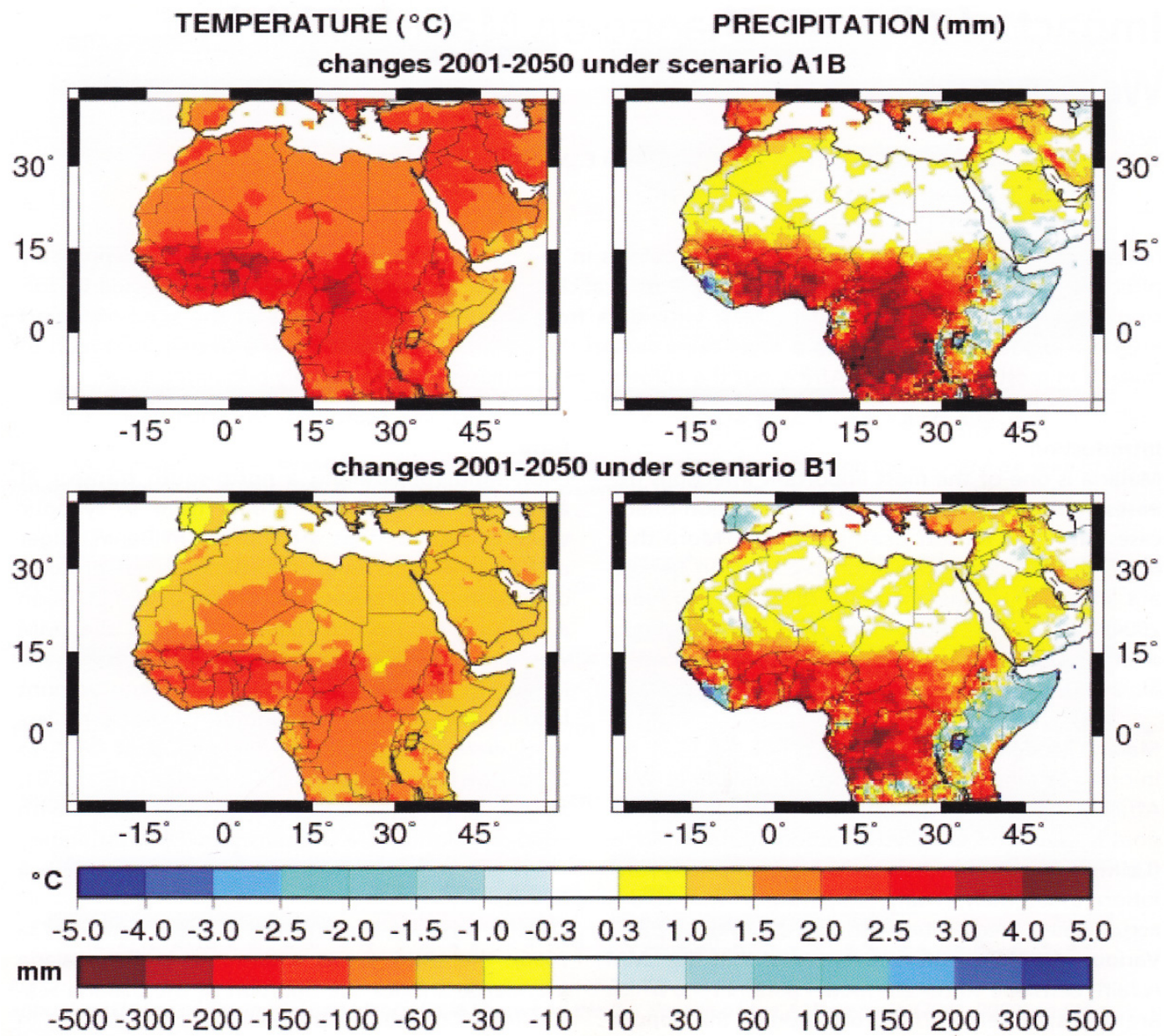


Many recent research studies attempted to simulate West African future rainfall and climate parameters throughout the 21 st century using atmosphere-ocean global climate models and relying on greenhouse gas emissions scenarios as outlined in the Intergovernmental Panel on Climate Change archives for Assessment Reports (AR3 \& 4). The recent Coordinated Regional Climate Downscaling Experiment-CORDEX initiative from the World Climate Research Program promotes running multiple RCM simulations at $50 \mathrm{~km}$ resolution for multiple regions including West Africa, highly expected to bring clarifications and improve the projections [56]. The CORDEX initiative includes the study of uncertainty due to structural errors of different GCMs and/or RCMs. Beyond CORDEX and apart from Paeth et al. [36,54], who nested REMO in the global circulation model ECHAM5/MPI-OM as described above, Patricola and Cook [57] also attempt to overcome the limitations of global models by nesting a higher resolution regional model, the Weather Research and Forecasting (WRF) model on a grid of $90 \mathrm{~km}$ resolution, over West Africa and for the second half of the $21 \mathrm{st}$ century. They found a very mixed rainfall change signal characterized by June-July drought, followed by copious rainfall towards the end of the summer [58]. Although focused on different time periods, both studies [36,54,57] favor desiccation, albeit with caveats regarding intraseasonal and spatial variability.

As an alternative to the above-described studies using relatively high-resolution regional climate models, many other studies [59-61] used atmosphere-ocean global climate models to run climate change experiments and have rather concluded a wetter climate for the first half of the 21 st century in reference to the 20th century contrary to REMO-based projections presented in Paeth et al. [36]. Cook and Vizy [62] have concluded no impact of climate change on projected West Africa rainfall, while Biasutti et al. [63] have argued towards uncertain rainfall projections.

The land use/cover classification used, considers 17 land use/cover types (Table 6 and Figure 10). A subsequent accuracy check shows that the overall accuracy is high (87\%) [64]. The land use/cover scenarios were computed in the framework of the European Union funded project RIVERTWIN [37]. The major driver for land use change is population growth and subsequent conversion of the natural savannah vegetation into settlements, roads, and a mosaic of fields by slash and burn clearance [65]. Two socio-economic scenarios have been set up: (1) La, stronger economic development, controlled urbanization, 3.2\% population growth per year; and (2) Lb, weak national economy, uncontrolled settlement and farmland development, 3.5\% population growth per year. For each scenario, the population growth has been translated into a specific demand for settlements and agricultural area according to the development of the national framework. This demand has been satisfied according to the proximity to roads and existing villages, new settlements and agricultural areas have been created leading to the land use distribution. The General Directorate for Water has selected several potential sites for future construction of multi-purpose reservoirs for large scale irrigation. Therefore, large areas of natural vegetation were also accordingly converted to croplands. With respect to the scenarios $\mathrm{La}$ and $\mathrm{Lb}$, change in the Ouémé land use/cover is expressed by the conversion of the natural vegetation including savannah into agricultural lands and pastures: $10 \%$ to $20 \%$ for the scenario La and $20 \%$ to $40 \%$ for the scenario $\mathrm{Lb}$. 
Table 6. Land use/cover categories, their area and percentage of total area for the Ouémé-Bonou catchment $\left(49,256 \mathrm{~km}^{2}\right)$. Values displayed in brackets are related to the Donga-Pont catchment $\left(586 \mathrm{~km}^{2}\right)$ [64]. SWAT model was adapted to consider almost all land use classes mentioned in the table.

\begin{tabular}{cccc}
\hline Land Use Categories & Land Use Code & Area $\left.\mathbf{( k m}^{\mathbf{2}}\right)$ & Percentage of Total Area \\
\hline Galery forest & GF & $1759(8.6)$ & $3.98(1.47)$ \\
Humid and dry dense forest & FD & $1220(0.4)$ & $2.76(0.06)$ \\
Swamp formations & FM & $17(0)$ & $0.04(0)$ \\
Riverine formations & FR & $107(0)$ & $0.24(0)$ \\
Woodland and woodland savannah & FCSB & $6716(8.6)$ & $15.2(1.47)$ \\
Flooding savannah & SM & $222(0)$ & $0.5(0)$ \\
Tree and shrub savannah & SA & 17231 & $38.99(48.74)$ \\
Saxicolous savannah & & $(285.8)$ & $0.71(0)$ \\
Grassland & SS & $313(0)$ & $0.03(0)$ \\
PH & $14(0)$ & 13713 & $31.03(47.77)$ \\
Mosaic of cropland and bush fallow & CJ & $(280.1)$ & $0.07(0)$ \\
Mosaic of cultivation with Parkia and Cashew trees & CJNA & $32(0)$ & $2.69(0)$ \\
Mosaic of cultivation with palm trees & CJP & $1189(0)$ & $0.29(0)$ \\
Industrial plantations & PI & $127(0)$ & $2.74(0.08)$ \\
Village plantations & PV & $1209(0.5)$ & $0.01(0)$
\end{tabular}

Figure 10. Land use/cover of the Ouémé-Bonou $\left(49,256 \mathrm{~km}^{2}\right)$ and the Donga-Pont catchments $\left(586 \mathrm{~km}^{2}\right)$. The legend is fully explained in Table 3. (a) reference map (2003); (b) La 2015-2019; (c) La 2025-2029; (d) Lb 2015-2019; (e) Lb 2025-2029 [37].

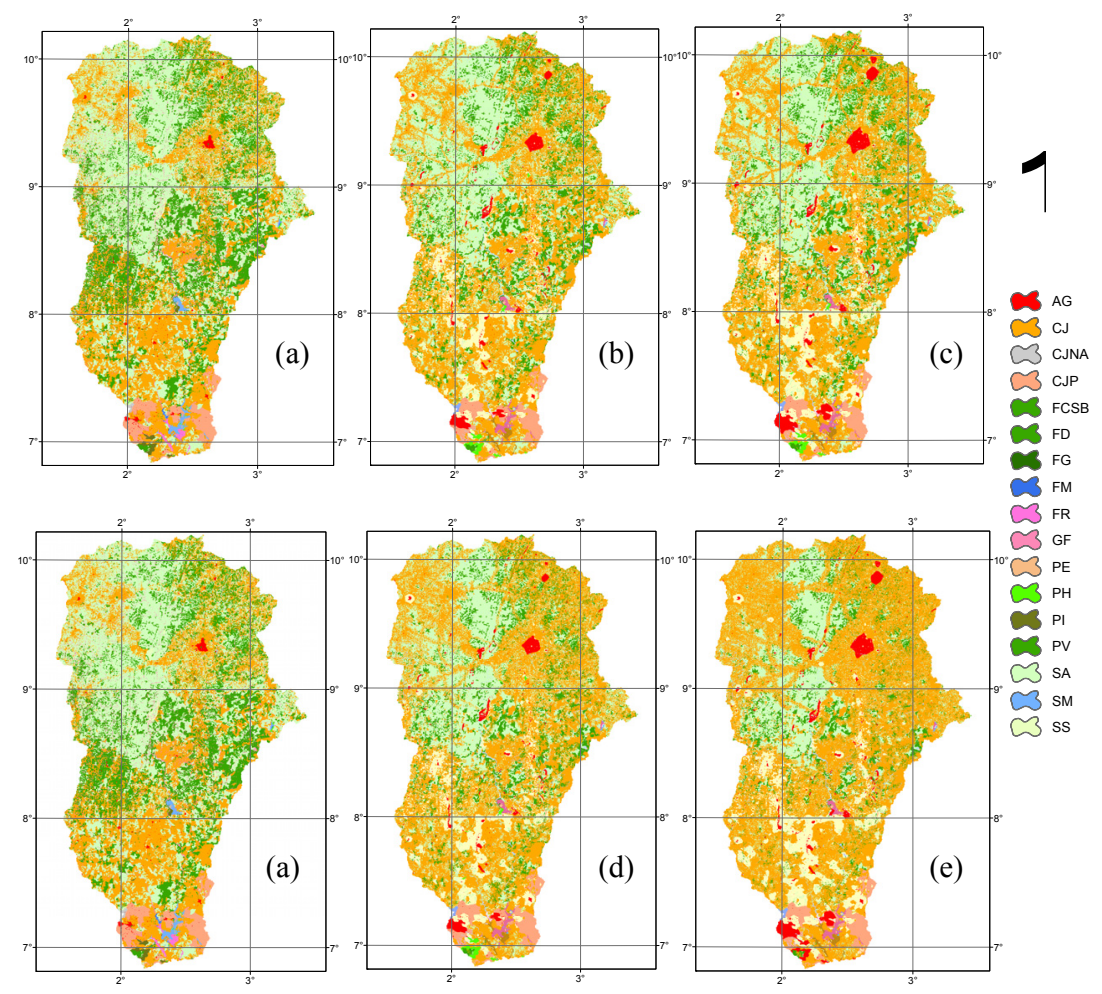




\section{Results and Discussion}

\subsection{Impacts of Climate Change}

Climate change impacts on key water balance components and sediment-organic $\mathrm{N}$ yield over time windows of 10 to 20 years for the Donga-Pont sub-catchment (Table 7 and Figure 11a) were computed to be consistent with other climate change impact studies. The Table and Figure show a decrease in rainfall all over the 10 -year and 20 -year time windows, resulting in a reduction of up to $22 \%$ of the simulated water-nutrient components for all scenarios except the scenario A1B over the time window 2010-2019. These results suggest significant impacts of year-to-year climate variability. To be consistent with the used land use scenarios 5-year time windows (Tables 8 and 9, Figure 11b,c) will be considered in the discussion as provided in the following paragraphs.

As shown in Tables 8 and 9, the simulated absolute surface runoff ranges from 100 to $140 \mathrm{~mm}$ per year for the Donga-Pont catchment $\left(586 \mathrm{~km}^{2}\right)$, while varying from 60 to $80 \mathrm{~mm}$ per year for the Ouémé-Bonou catchment $\left(49,256 \mathrm{~km}^{2}\right)$, due to the significantly different catchment sizes with a likely slight effect of the higher rate of agricultural lands in the Donga-Pont catchment compared to the Ouémé-Bonou catchment (cf. Table 6). In fact, due to unsustainable agriculture practices over the region, higher surface runoff may be associated to larger rate of agricultural lands.

Table 7. Simulated SWAT components under climate scenarios (with unchanged land use map derived from 2003 Landsat image). Deviation (in \%) from the reference scenario (2000-2009) are shown in brackets.

\begin{tabular}{|c|c|c|c|c|c|c|c|c|c|c|c|c|c|}
\hline \multirow{2}{*}{$\begin{array}{c}\text { Donga-Pont }\left(\mathbf{5 8 6} \mathbf{~ k m}^{2}\right) \\
\text { Rainfall }\left(\mathrm{mm} \mathrm{a}^{-1}\right)\end{array}$} & \multirow{2}{*}{ 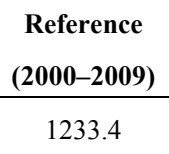 } & \multicolumn{2}{|c|}{$\begin{array}{c}\text { A1B } \\
(2010-2019)\end{array}$} & \multicolumn{2}{|c|}{$\begin{array}{c}\text { A1B } \\
(2020-2029)\end{array}$} & \multicolumn{2}{|c|}{$\begin{array}{c}\text { A1B } \\
(2010-2029)\end{array}$} & \multicolumn{2}{|c|}{$\begin{array}{c}\text { B1 } \\
(2010-2019)\end{array}$} & \multicolumn{2}{|c|}{$\begin{array}{c}\text { B1 } \\
(2020-2029)\end{array}$} & \multicolumn{2}{|c|}{$\begin{array}{c}\text { B1 } \\
(2010-2029)\end{array}$} \\
\hline & & 1196.6 & $(-3)$ & 1107.2 & $(-10)$ & 1151.9 & $(-7)$ & 1145.5 & $(-7)$ & 1126.2 & $(-9)$ & 1135.8 & $(-8)$ \\
\hline Water yield $\left(\mathrm{mm} \mathrm{a}^{-1}\right)$ & 254.7 & 282.8 & (11) & 206.6 & $(-19)$ & 244.7 & $(-4)$ & 238.2 & $(-6)$ & 219.4 & $(-14)$ & 228.8 & $(-10)$ \\
\hline Groundwater flow $\left(\mathrm{mm} \mathrm{a}^{-1}\right)$ & 117.6 & 122.7 & (4) & 91.4 & $(-22)$ & 107.0 & $(-9)$ & 105.3 & $(-10)$ & 99.5 & $(-15)$ & 102.4 & $(-13)$ \\
\hline Surface runoff $\left(\mathrm{mm} \mathrm{a}^{-1}\right)$ & 137.2 & 158.8 & (16) & 113.8 & $(-17)$ & 136.3 & $(-1)$ & 131.5 & $(-4)$ & 118.5 & $(-14)$ & 125.0 & $(-9)$ \\
\hline Act. Evapotranspiration $\left(\mathrm{mm} \mathrm{a}^{-1}\right)$ & 923.7 & 840.9 & $(-9)$ & 849.4 & $(-8)$ & 845.1 & $(-9)$ & 848.6 & $(-8)$ & 846.7 & $(-8)$ & 847.6 & $(-8)$ \\
\hline Sediment yield (ton $\mathrm{ha}^{-1} \mathrm{a}^{-1}$ ) & 0.4 & 0.5 & (17) & 0.4 & $(-5)$ & 0.4 & (6) & 0.4 & $(-2)$ & 0.4 & $(-8)$ & 0.4 & $(-5)$ \\
\hline Organic $\mathrm{N}$ load $\left(\mathrm{kg} \mathrm{ha}^{-1} \mathrm{a}^{-1}\right)$ & 0.7 & 0.8 & (11) & 0.6 & $(-10)$ & 0.7 & (0) & 0.7 & $(-5)$ & 0.6 & $(-9)$ & 0.7 & $(-7)$ \\
\hline
\end{tabular}

Sediment yield was more important at the Donga-Pont catchment scale, ranging from 0.3 to 0.4 ton $\cdot \mathrm{ha}^{-1} \cdot \mathrm{a}^{-1}$ against 0.3 ton $\cdot \mathrm{ha}^{-1} \cdot \mathrm{a}^{-1}$ for the Ouémé-Bonou catchment. This can be explained by the higher rate of agricultural lands in the Donga-Pont catchment compared to the Ouémé-Bonou catchment (cf. Table 6). Thus, due to inadequate tillage and unsustainable practices, sediments are very susceptible to loading. Conversely, the simulated organic nitrogen yields for the Ouémé-Bonou catchment (roughly 1.2 ton $\cdot \mathrm{ha}^{-1} \cdot \mathrm{a}^{-1}$ ) were twice the computed amount for the Donga-Pont catchment ( 0.6 to 0.7 ton $\cdot \mathrm{ha}^{-1} \cdot \mathrm{a}^{-1}$ ). This can be easily understood since due to the higher rate of agricultural lands in the Donga-Pont catchment, the topsoils are more degraded and very poor humus and organic matters are available for loading. 
Figure 11. Simulated trends under climate scenarios with land use from the year 2003. (a) Donga-Pont: trend over 20 years; (b) Donga-Pont: trend over a 5-year time window; (c) Ouémé-Bonou: trend over a 5-year time window.

(a)
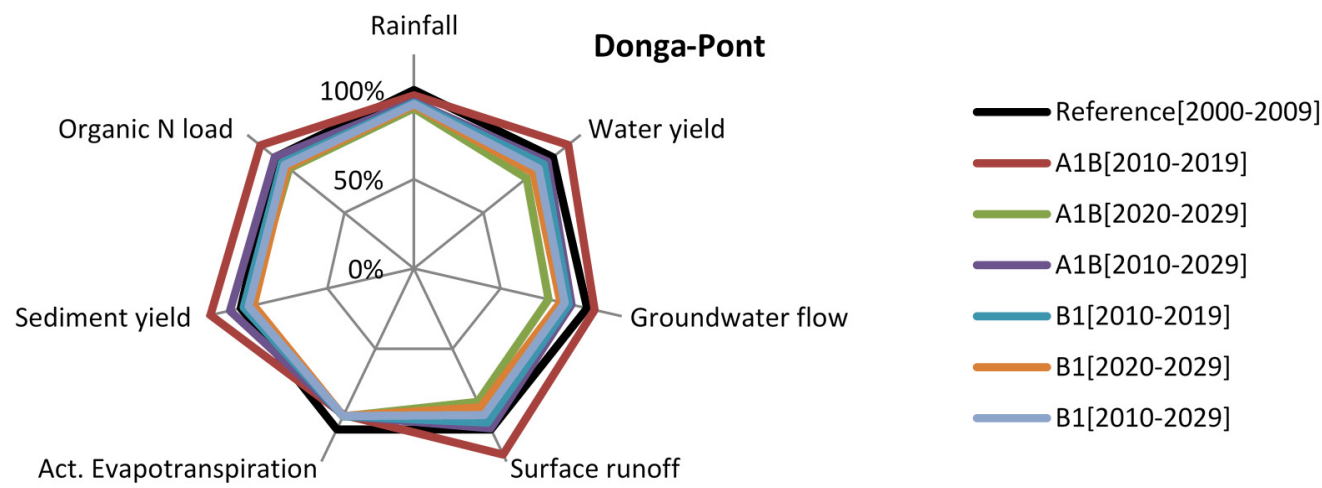

(b)
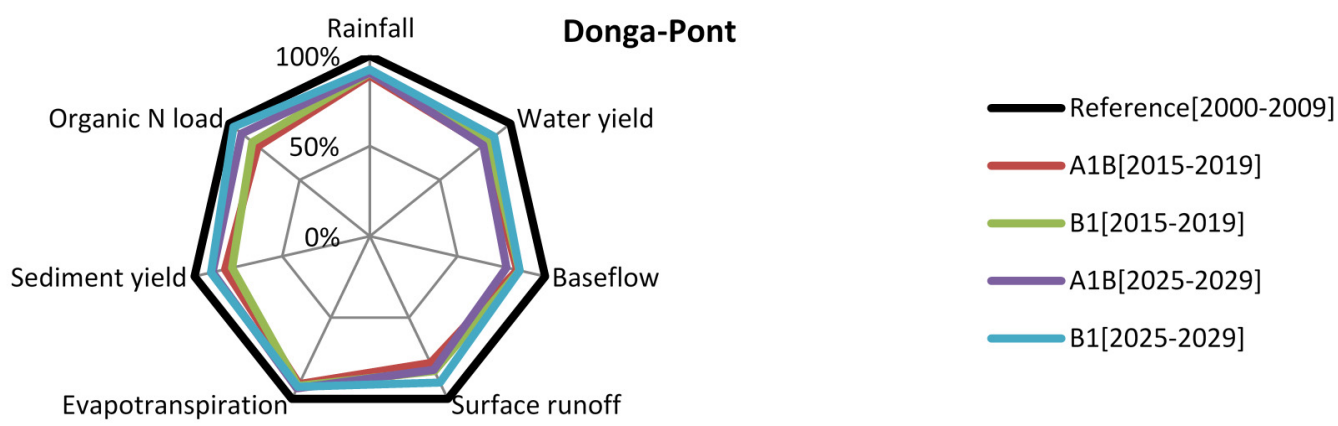

(c)
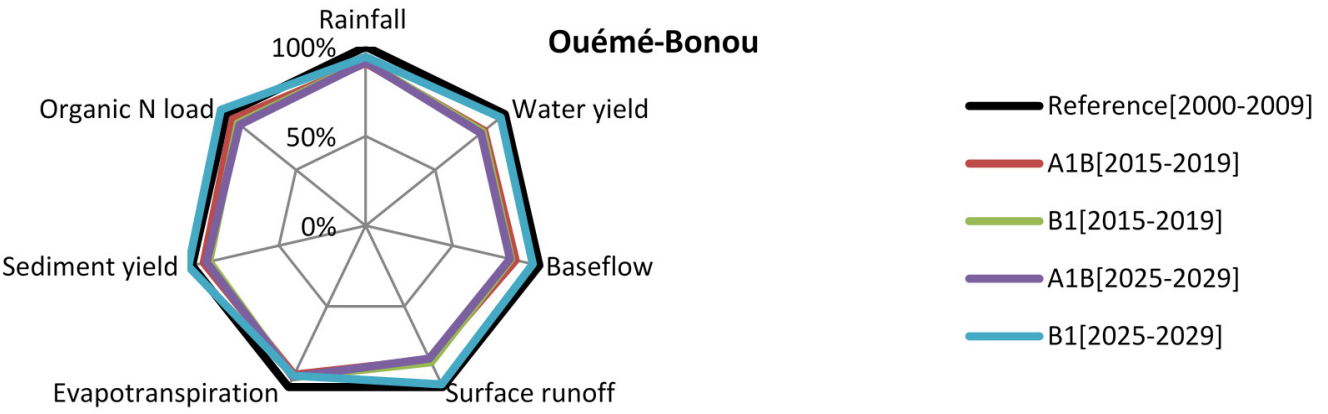

Table 8. Simulated SWAT components under climate scenarios (with unchanged land use map derived from 2003 Landsat image). Deviation (in \%) from the reference scenario (2000-2009) are shown in brackets.

\begin{tabular}{ccccccccccc}
\hline \multirow{2}{*}{ Donga-Pont $\left(\mathbf{5 8 6} \mathbf{~ k m}^{2}\right)$} & $\begin{array}{c}\text { Reference } \\
\text { (2000-2009) }\end{array}$ & \multicolumn{2}{c}{ A1B } & \multicolumn{2}{c}{ B1 } & \multicolumn{2}{c}{ A1B } & \multicolumn{2}{c}{ B1 } \\
(2015-2019) & $\mathbf{( 2 0 1 5 - 2 0 1 9 )}$ & \multicolumn{2}{c}{$\mathbf{( 2 0 2 5 - 2 0 2 9 )}$} & (2025-2029) \\
\hline Rainfall $\left(\mathrm{mm} \mathrm{a}^{-1}\right)$ & 1233.4 & 1096.7 & $(-11)$ & 1113.9 & $(-10)$ & 1116.0 & $(-10)$ & 1138.0 & $(-8)$ \\
Water yield $\left(\mathrm{mm} \mathrm{a}^{-1}\right)$ & 254.7 & 206.9 & $(-19)$ & 215.5 & $(-15)$ & 205.6 & $(-19)$ & 225.3 & $(-12)$ \\
Groundwater flow $\left(\mathrm{mm} \mathrm{a}^{-1}\right)$ & 117.6 & 98.9 & $(-16)$ & 100.3 & $(-15)$ & 91.6 & $(-22)$ & 100.5 & $(-15)$ \\
Surface runoff $\left(\mathrm{mm} \mathrm{a}^{-1}\right)$ & 137.2 & 106.7 & $(-22)$ & 113.7 & $(-17)$ & 112.6 & $(-18)$ & 123.4 & $(-10)$ \\
Act. Evapotranspiration $\left(\mathrm{mm} \mathrm{a}^{-1}\right)$ & 923.7 & 839.1 & $(-9)$ & 849.2 & $(-8)$ & 863.6 & $(-7)$ & 854.1 & $(-8)$ \\
Sediment yield $\left(\right.$ ton ha $\left.{ }^{-1} \mathrm{a}^{-1}\right)$ & 0.4 & 0.3 & $(-25)$ & 0.3 & $(-25)$ & 0.4 & $(0)$ & 0.4 & $(0)$ \\
Organic N load $\left(\mathrm{kg} \mathrm{ha}^{-1} \mathrm{a}^{-1}\right)$ & 0.7 & 0.6 & $(-14)$ & 0.6 & $(-14)$ & 0.6 & $(-14)$ & 0.7 & $(0)$ \\
\hline
\end{tabular}


Table 9. Simulated SWAT components under climate scenarios (with unchanged land use map derived from 2003 Landsat image). Deviation (in \%) from the reference scenario (2000-2009) are shown in brackets.

\begin{tabular}{|c|c|c|c|c|c|c|c|c|c|}
\hline \multirow{2}{*}{$\begin{array}{c}\text { Ouémé-Bonou }(49,256 \text { km²) } \\
\text { Rainfall }\left(\mathrm{mm} \mathrm{a}^{-1}\right)\end{array}$} & \multirow{2}{*}{$\begin{array}{c}\begin{array}{c}\text { Reference } \\
\mathbf{( 2 0 0 0 - 2 0 0 9 )}\end{array} \\
1138.9\end{array}$} & \multicolumn{2}{|c|}{$\begin{array}{c}\text { A1B } \\
(2015-2019) \\
\end{array}$} & \multicolumn{2}{|c|}{$\begin{array}{c}\text { B1 } \\
(2015-2019) \\
\end{array}$} & \multicolumn{2}{|c|}{$\begin{array}{c}\text { A1B } \\
(2025-2029) \\
\end{array}$} & \multicolumn{2}{|c|}{$\begin{array}{c}\text { B1 } \\
(2025-2029) \\
\end{array}$} \\
\hline & & 1035.2 & $(-9)$ & 1045.2 & $(-8)$ & 1041.5 & $(-9)$ & 1074.9 & $(-6)$ \\
\hline Water yield $\left(\mathrm{mm} \mathrm{a}^{-1}\right)$ & 224.6 & 191.4 & $(-15)$ & 189.0 & $(-16)$ & 186.2 & $(-17)$ & 218.0 & $(-3)$ \\
\hline Groundwater flow $\left(\mathrm{mm} \mathrm{a}^{-1}\right)$ & 147.6 & 127.5 & $(-14)$ & 123.7 & $(-16)$ & 122.8 & $(-17)$ & 142.2 & $(-4)$ \\
\hline Surface runoff $\left(\mathrm{mm} \mathrm{a}^{-1}\right)$ & 77.0 & 63.9 & $(-17)$ & 65.3 & $(-15)$ & 63.4 & $(-18)$ & 75.8 & $(-2)$ \\
\hline Act. Evapotranspiration $\left(\mathrm{mm} \mathrm{a}^{-1}\right)$ & 794.8 & 734.3 & $(-8)$ & 747.5 & $(-6)$ & 745.8 & $(-6)$ & 740.2 & $(-7)$ \\
\hline Sediment yield (ton ha ${ }^{-1} \mathrm{a}^{-1}$ ) & 0.3 & 0.3 & (0) & 0.3 & (0) & 0.3 & (0) & 0.3 & (0) \\
\hline Organic $\mathrm{N}$ load $\left(\mathrm{kg} \mathrm{ha}^{-1} \mathrm{a}^{-1}\right)$ & 1.2 & 1.1 & $(-8)$ & 1.1 & $(-8)$ & 1.1 & $(-8)$ & 1.2 & (0) \\
\hline
\end{tabular}

In both investigated scales, annual sediment yield and actual evapotranspiration have significantly decreased (of up to 20\%) over the simulated years (2000 to 2029). Groundwater flow decreased significantly from $15 \%$ to $22 \%$ for the Donga-Pont catchment and from $4 \%$ to $17 \%$ for the Ouémé-Bonou catchment. Figure 11b,c shows a decreasing trend for all the simulated components (of up to $20 \%$ ), regardless the different scenarios, but more pronounced for the Donga-Pont catchment.

One may conclude that differences in water balance components as well as nutrient load rate while moving between different catchment scales are functions of rate of agricultural lands, which are more sensitive than natural vegetations. Similar results were found in the upper Ouémé catchment (about $15,000 \mathrm{~km}^{2}$ ) using the SWAT model and the same IPCC SRES scenarios A1B and B1 $[9,15]$.

\subsection{Impacts of Land Use Change}

As indicated in the Section 2.3, changes in the Ouémé land use according to the scenarios La and $\mathrm{Lb}$ are mainly expressed by the conversion of savannah into croplands and pastures in a range of $10 \%$ to $20 \%$ of the agricultural lands for the scenario La (stronger economic development, controlled urbanization, $3.2 \%$ population growth per year) and $20 \%$ to $40 \%$ for the scenario Lb (weak national economy, uncontrolled settlement and farmland development, 3.5\% population growth per year). Accordingly, an increasing surface runoff was simulated (from 2000 to 2029) for both scenarios $\mathrm{La}$ and $\mathrm{Lb}$, but in a pronounced way for the scenario Lb (Table 10 and Figure 12). These increases range from $9 \%$ to $27 \%$ for the Donga-Pont catchment and between $22 \%$ and $57 \%$ for the Ouémé-Bonou catchment.

In spite of this simulated increase for the surface runoff, water yield has change in a very low rate (roughly $\pm 5 \%$ ), forcing a decrease of the groundwater flow (between $-3 \%$ and $-33 \%$ for the Donga-Pont catchment and between $-7 \%$ and $-18 \%$ for the Ouémé-Bonou). This reveals the proof of decrease of the infiltration rate over the study area, and a severe threat to its groundwater systems. Sediment yield has increased from $25 \%$ to $75 \%$ for the Donga-Pont catchment and from $33 \%$ to $66 \%$ for the Ouémé-Bonou catchment. Organic nitrogen load has increased from 14\% to 43\% for the Donga-Pont catchment and from $17 \%$ to $58 \%$ for the Ouémé-Bonou due to conversion of natural vegetation to new cropland, which are more important at the Ouémé-Bonou scale. 
Actual evapotranspiration has decreased slightly from $0.5 \%$ to $1.1 \%$ for the Donga-Pont catchment and $0.8 \%$ to $2 \%$ for the Ouémé-Bonou catchment. For this trend the land use scenario Lb differs from the other by showing the highest underlying simulated rates, as already discussed above for the other components.

Table 10. Simulated SWAT components under land use scenarios (with unchanged climate condition of the period 2000 to 2009). Deviation (in \%) from the reference scenario (2000-2009) are shown in brackets.

\begin{tabular}{|c|c|c|c|c|c|c|c|c|c|}
\hline \multirow{2}{*}{$\begin{array}{c}\text { Donga-Pont }\left(\mathbf{5 8 6} \mathbf{~ k m}^{\mathbf{2}}\right) \\
\text { Rainfall }\left(\mathrm{mm} \mathrm{a}^{-1}\right)\end{array}$} & \multirow{2}{*}{$\begin{array}{c}\begin{array}{c}\text { Reference } \\
\mathbf{( 2 0 0 0 - 2 0 0 9 )}\end{array} \\
1233.4\end{array}$} & \multicolumn{2}{|c|}{$\begin{array}{c}\text { La } \\
(2015-2019)\end{array}$} & \multicolumn{2}{|c|}{$\begin{array}{c}\text { Lb } \\
(2015-2019)\end{array}$} & \multicolumn{2}{|c|}{$\begin{array}{c}\text { La } \\
(2025-2029)\end{array}$} & \multicolumn{2}{|c|}{$\begin{array}{c}\text { Lb } \\
(2025-2029)\end{array}$} \\
\hline & & 1233.4 & $(0)$ & 1233.4 & $(0)$ & 1233.4 & $(0)$ & 1233.4 & $(0)$ \\
\hline Water yield $\left(\mathrm{mm} \mathrm{a}^{-1}\right)$ & 254.7 & 228.7 & $(-10)$ & 236.7 & $(-7)$ & 267.0 & (5) & 263.4 & (3) \\
\hline Groundwater flow $\left(\mathrm{mm} \mathrm{a}^{-1}\right)$ & 117.6 & 78.8 & $(-33)$ & 79.0 & $(-33)$ & 113.6 & $(-3)$ & 88.8 & $(-24)$ \\
\hline Surface runoff $\left(\mathrm{mm} \mathrm{a}^{-1}\right)$ & & 149.1 & $(9)$ & 157.0 & (14) & 152.4 & (11) & 174.3 & $(27)$ \\
\hline Act. Evapotranspiration $\left(\mathrm{mm} \mathrm{a}^{-1}\right)$ & 923.7 & 913.7 & $(-1)$ & 918.0 & $(-1)$ & 915.3 & $(-1)$ & 919.1 & $(0)$ \\
\hline Sediment yield (ton $\mathrm{ha}^{-1} \mathrm{a}^{-1}$ ) & & 0. & (25) & 0.6 & (50) & 0.5 & 25) & 0.7 & (75) \\
\hline Organic $\mathrm{N}$ load $\left(\mathrm{kg} \mathrm{ha}^{-1} \mathrm{a}^{-1}\right)$ & & 0.8 & (14) & 0.9 & (29) & 0.8 & (14) & 1.0 & (43) \\
\hline \multicolumn{10}{|l|}{ Ouémé-Bonou $\left(49,256 \mathrm{~km}^{2}\right)$} \\
\hline & & & (D) & 1138 & (0) & 113 & (0) & 1138.9 & (0) \\
\hline Water yield $\left(\mathrm{mm} \mathrm{a}^{-1}\right)$ & 224.6 & 231.5 & (3) & 238.8 & (6) & 233.6 & (4) & 243.0 & $(8)$ \\
\hline Groundwater flow $\left(\mathrm{mm} \mathrm{a}^{-1}\right)$ & 147.6 & 137.9 & $(-7)$ & 128.8 & $(-13)$ & 133.9 & $(-9)$ & 121.7 & $(-18)$ \\
\hline Surface runoff $\left(\mathrm{mm} \mathrm{a}^{-1}\right)$ & 77.0 & 93.7 & (22) & 110.0 & (43) & 99.7 & (29) & 121.3 & (58) \\
\hline Act. Evapotranspiration $\left(\mathrm{mm} \mathrm{a}^{-1}\right)$ & 794.8 & 788.9 & $(-1)$ & 782.1 & $(-2)$ & 787.4 & $(-1)$ & 778.8 & $(-2)$ \\
\hline Sediment yield (ton $\mathrm{ha}^{-1} \mathrm{a}^{-1}$ ) & 0.3 & 0.4 & (33) & 0.4 & (33) & 0.4 & (33) & 0.5 & (67) \\
\hline Organic N load $\left(\mathrm{kg} \mathrm{ha}^{-1} \mathrm{a}^{-1}\right)$ & 1.2 & 1.4 & (17) & 1.7 & $(42)$ & 1.5 & $(25)$ & 1.9 & $(58)$ \\
\hline
\end{tabular}

Figure 12. Simulated trends under land use scenarios (with unchanged climate: 2000-2009).

(a) Donga-Pont; (b) Ouémé-Bonou.

(a)
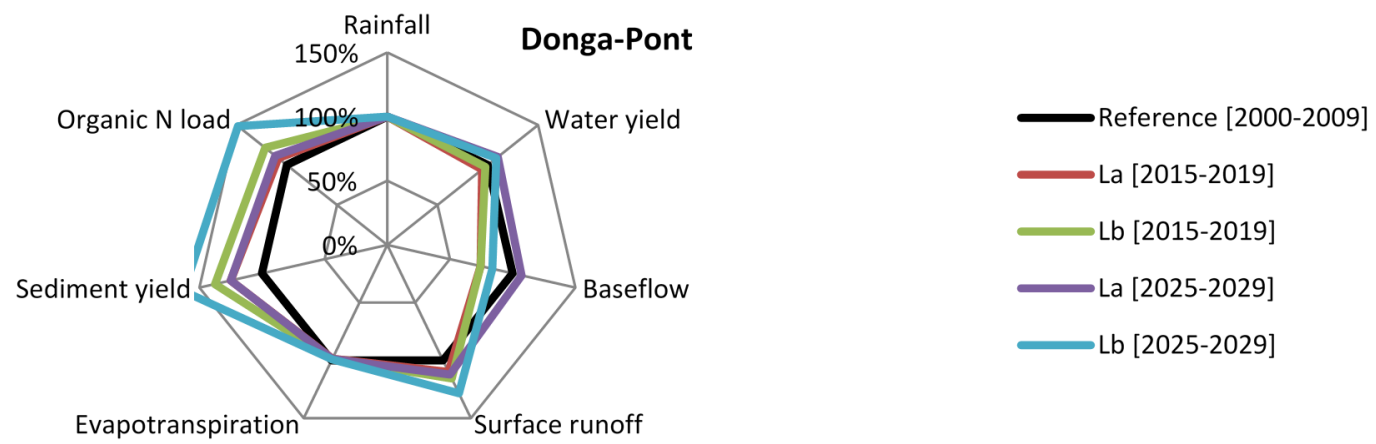

(b)
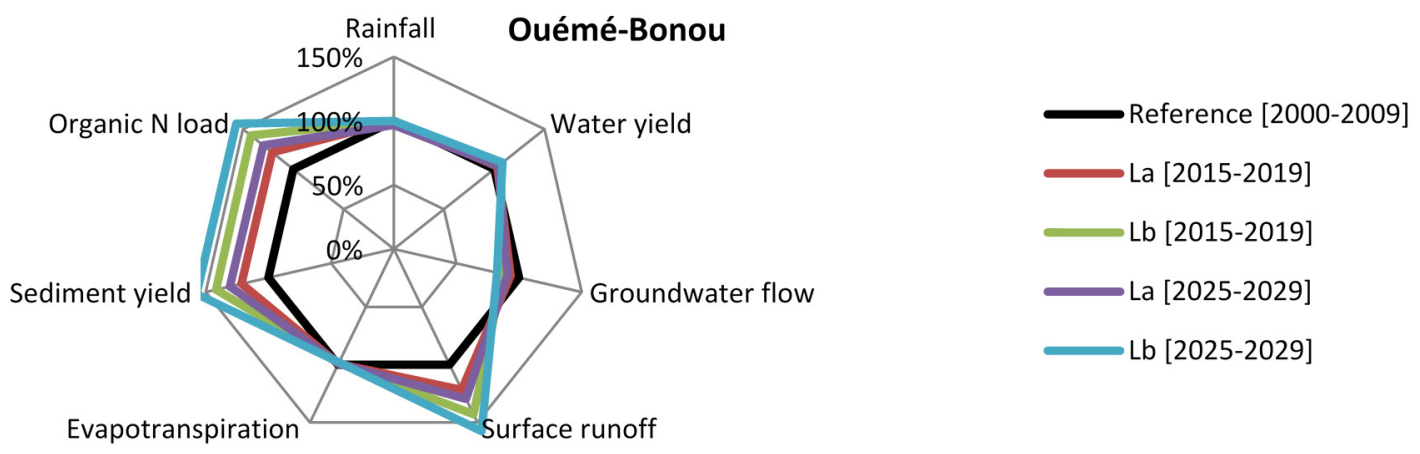
In summary (combining the Sections 3.1 and 3.2), surface runoff was found more sensitive to land use change $(+22 \%$ to $+75 \%$ of changes $)$ than climate change ( $-5 \%$ to $-20 \%$ of changes), evapotranspiration was more sensitive to climate change ( -8 to $-12 \%$ of changes) than land use change ( $-0.5 \%$ to $-2 \%$ of changes) and groundwater flow was less sensitive to climate change ( $-4 \%$ to $-22 \%$ ) than land use change ( $-9 \%$ to $-57 \%)$. Sediment yield was more sensitive to land use ( $+25 \%$ to $+75 \%)$ than climate change $(-25 \%$ to $0 \%)$. Organic nitrogen load was more sensitive to land use change $(+14 \%$ to $+58 \%)$ than climate change $(-8 \%$ to $-14 \%)$.

At the large catchment scale (Ouémé-Bonou), sediment yield has decreased $(-25 \%$ for the climate scenarios and $-57 \%$ for the land use scenarios) and organic nitrogen load has increased (100\% for the climate scenarios and $175 \%$ for the land use scenarios) in reference to the meso scale catchment (Donga-Pont).

Li et al. [22] modeled the hydrological impact of land use change in the Niger and the Lake Chad basins (West Africa) and found that a deforestation percentage below 50\% has no significant impact on the stream flow, but a total deforestation increases the annual stream runoff by $35 \%-65 \%$. This finding is very contrasting the results obtained here, where a progressive conversion of natural vegetation to cropland to a maximum of $40 \%$ over 30 years has increased the surface runoff by $22 \%-57 \%$ and decreased the groundwater flow by $7 \%-18 \%$.

\subsection{Impacts of Combined Climate and Land Use Scenarios}

In reference to the results discussed in the Sections 3.1 and 3.2, an overview of combined land use and climate change scenario effects on the degradation trend presented in Table 11 and Figure 13 identified climate change as the major driver of the changes in water yield and actual evapotranspiration. In the meantime, land use changes raises as the major driver affecting surface runoff, groundwater flow, sediment yield and organic nitrogen load. Stronger effects of climate change were computed for the time period 2015-2019 in the Donga-Pont catchment scale, which have been significantly but not completely compensated by the land use change effects over the time period 2025-2029.

At the Donga-Pont scale (Table 12 and Figure 14, time period 2025-2029), annual surface runoff may change from $-8 \%$ to $+17 \%$. The decrease $(-8 \%)$ (scenarios La + A1B) was mainly driven by climate change, while land use change effects have mainly resulted in an increase $(+17 \%)$ (scenarios $\mathrm{La}+\mathrm{B} 1, \mathrm{Lb}+\mathrm{A} 1 \mathrm{~B}$ and $\mathrm{Lb}+\mathrm{B} 1)$. Sediment yield increased for all the scenarios from $12.5 \%$ to $50 \%$, and organic nitrogen load also has increased from $1.4 \%$ to $46 \%$ (driven by land use changes). Under climate change effects, water yield has changed from $-9 \%$ to $+1.6 \%$, groundwater flow from $-29 \%$ to $1 \%$ and evapotranspiration from $-9 \%$ to $-7.5 \%$.

At the Ouémé-Bonou scale (Table 12 and Figure 14, time period 2025-2029), annual surface runoff may change from $+5.7 \%$ to $+42 \%$ for all the scenarios, driven by land use change. Sediment yield increased for all the scenarios from $15.6 \%$ to $41 \%$, and organic nitrogen load also has increased from $15 \%$ to $47 \%$ (driven by land use changes). Under climate change effects, water yield has changed from $-14 \%$ to $+0.6 \%$, groundwater flow from $-30.5 \%$ to $-16 \%$ and evapotranspiration from $-8.4 \%$ to $-7 \%$. 
Table 11. Simulated SWAT components under land use and climate scenarios (2015 to 2019). Deviation (in \%) from the reference scenario (2000-2009) are shown in brackets.

\begin{tabular}{|c|c|c|c|c|c|c|c|c|c|}
\hline \multirow{2}{*}{$\begin{array}{c}\text { Donga-Pont }\left(\mathbf{5 8 6} \mathbf{~ k m}^{\mathbf{2}}\right) \\
\text { Rainfall }\left(\mathrm{mm} \mathrm{a}^{-1}\right)\end{array}$} & \multirow{2}{*}{$\begin{array}{c}\begin{array}{c}\text { Reference } \\
(\mathbf{2 0 0 0 - 2 0 0 9 )}\end{array} \\
1233.4\end{array}$} & \multicolumn{2}{|c|}{$\begin{array}{c}\text { La \& A1B } \\
(2015-2019)\end{array}$} & \multicolumn{2}{|c|}{$\begin{array}{c}\text { La \& B1 } \\
(2015-2019)\end{array}$} & \multicolumn{2}{|c|}{$\begin{array}{c}\text { Lb \& A1B } \\
(2015-2019)\end{array}$} & \multicolumn{2}{|c|}{$\begin{array}{c}\text { Lb \& B1 } \\
(2015-2019)\end{array}$} \\
\hline & & 1096.7 & $(-11)$ & 1113.9 & $(-10)$ & 1096.7 & $(-11)$ & 1113.9 & $(-10)$ \\
\hline Water yield $\left(\mathrm{mm} \mathrm{a}^{-1}\right)$ & 254.7 & 191.7 & $(-21)$ & 201.1 & $(-17)$ & 199.1 & $(-18)$ & 206.8 & $(-15)$ \\
\hline Groundwater flow $\left(\mathrm{mm} \mathrm{a}^{-1}\right)$ & 7.6 & 74.1 & $(-30)$ & 76.6 & $(-28)$ & 74.5 & $(-30)$ & 75.1 & $(-29)$ \\
\hline Surface runoff $\left(\mathrm{mm} \mathrm{a}^{-1}\right)$ & & 116.4 & $(-14)$ & 123.1 & $(-9)$ & 123.5 & $(-9)$ & 130.4 & $(-4)$ \\
\hline Act. Evapotranspiration $\left(\mathrm{mm} \mathrm{a}^{-1}\right)$ & 923.7 & 831.7 & $(-10)$ & 841.5 & $(-9)$ & 833.6 & $(-10)$ & 843.7 & $(-9)$ \\
\hline Sediment yield (ton ha ${ }^{-1} \mathrm{a}^{-1}$ ) & & 0 & $(20)$ & 0.4 & $(-8)$ & 0.5 & $(15)$ & 0.4 & (7) \\
\hline Organic $\mathrm{N}$ load $\left(\mathrm{kg} \mathrm{ha}^{-1} \mathrm{a}^{-1}\right)$ & & 0.5 & $(-29)$ & 0.6 & $(-10)$ & 0.7 & $(0)$ & 0.7 & (3) \\
\hline \multicolumn{10}{|l|}{ Ouémé-Bonou $(49,256$ km²) } \\
\hline & & & $(-9)$ & & $(-8)$ & 103 & $(-9)$ & 1045.2 & $(-8)$ \\
\hline Water yield $\left(\mathrm{mm} \mathrm{a}^{-1}\right)$ & 224.6 & 195.9 & $(-13)$ & 194.1 & $(-14)$ & 201.1 & $(-10)$ & 200.1 & $(-11)$ \\
\hline Groundwater flow $\left(\mathrm{mm} \mathrm{a}^{-1}\right)$ & 147.6 & 120.2 & $(-19)$ & 116.0 & $(-21)$ & 113.9 & $(-23)$ & 109.5 & $(-26)$ \\
\hline Surface runoff $\left(\mathrm{mm} \mathrm{a}^{-1}\right)$ & 77.0 & 75.7 & $(-2)$ & 78.1 & $(1)$ & 87.3 & (13) & 90.6 & (18) \\
\hline Act. Evapotranspiration $\left(\mathrm{mm} \mathrm{a}^{-1}\right)$ & 794.8 & 730.8 & $(-8)$ & 743.4 & $(-6)$ & 726.2 & $(-9)$ & 738.1 & $(-7)$ \\
\hline Sediment yield (ton $\mathrm{ha}^{-1} \mathrm{a}^{-1}$ ) & 0.3 & 0.4 & (9) & 0.3 & $(6)$ & 0.4 & (25) & 0.4 & (22) \\
\hline Organic N load $\left(\mathrm{kg} \mathrm{ha}^{-1} \mathrm{a}^{-1}\right)$ & 1.2 & 1.3 & (13) & 1.3 & (9) & 1.5 & (29) & 1.5 & (26) \\
\hline
\end{tabular}

Figure 13. Simulated trends under land use and climate scenarios (2015 to 2019).

(a) Donga-Pont; (b) Ouémé-Bonou.
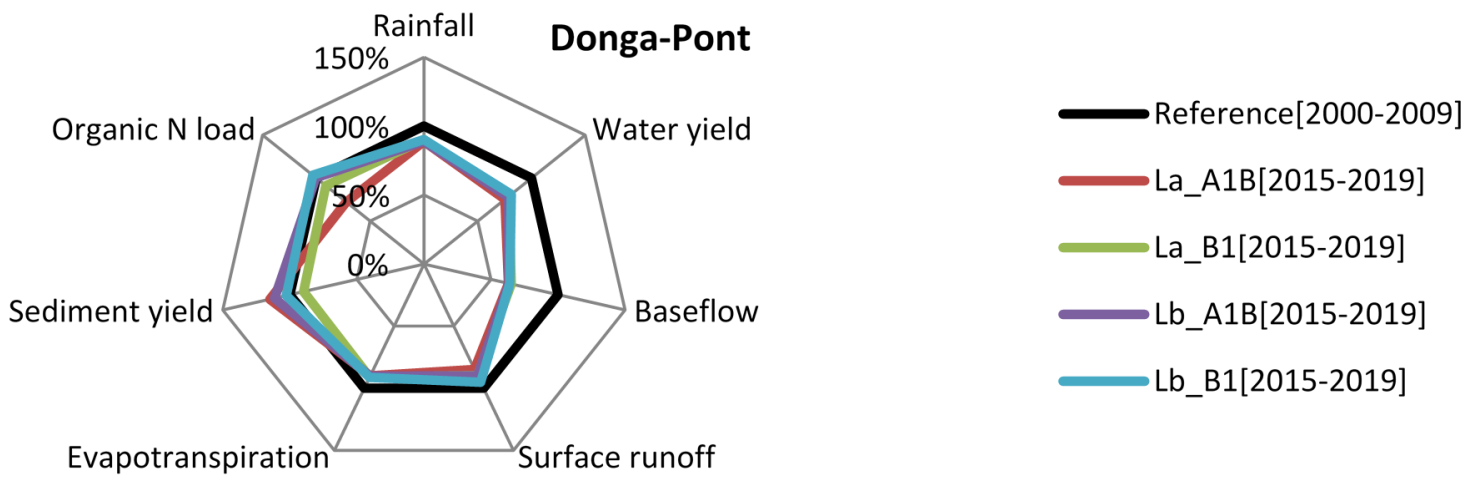

(a)
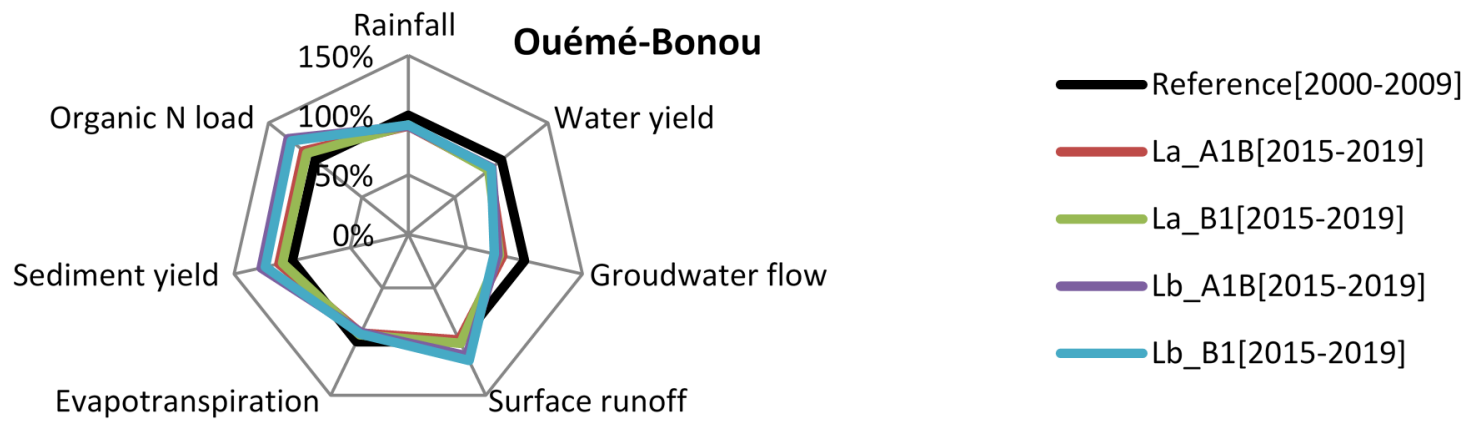

(b)

Regardless the modeling scale, the simulated impacts for the land use and climate change scenarios, over the simulated period 2000 to 2029 (30 years) may be summarized as follow: (1) surface runoff, groundwater flow, sediment and organic nitrogen load are found mainly sensitive to land use change 
with roughly $-8 \%$ to $50 \%$ of changes; and (2) water yield and evapotranspiration are found more sensitive to climate change with roughly $-31 \%$ to $+2 \%$ of changes as consequence of rainfall reduction (cf. Section 2.3).

Table 12. Simulated SWAT components under land use and climate scenarios (2025 to 2029). Deviation (in \%) from the reference scenario (2000-2009) are shown in brackets.

\begin{tabular}{|c|c|c|c|c|c|c|c|c|c|}
\hline \multirow{2}{*}{$\begin{array}{c}\text { Donga-Pont }\left(586 \mathbf{~ k m}^{2}\right) \\
\text { Rainfall }\left(\mathrm{mm} \mathrm{a}^{-1}\right)\end{array}$} & \multirow{2}{*}{$\begin{array}{c}\begin{array}{c}\text { Reference } \\
\text { (2000-2009) }\end{array} \\
1233.4\end{array}$} & \multicolumn{2}{|c|}{$\begin{array}{c}\text { La \& A1B } \\
(2025-2029)\end{array}$} & \multicolumn{2}{|c|}{$\begin{array}{c}\text { La \& B1 } \\
(2025-2029)\end{array}$} & \multicolumn{2}{|c|}{$\begin{array}{c}\text { Lb \& A1B } \\
(2025-2029)\end{array}$} & \multicolumn{2}{|c|}{$\begin{array}{c}\text { Lb \& B1 } \\
(2025-2029)\end{array}$} \\
\hline & & 1116.0 & $(-10)$ & 1138.0 & $(-8)$ & 1116.0 & $(-10)$ & 1138.0 & $(-8)$ \\
\hline Water yield $\left(\mathrm{mm} \mathrm{a}^{-1}\right)$ & 254.7 & 221.9 & $(-9)$ & 244.9 & (1) & 221.8 & $(-9)$ & 246.7 & (2) \\
\hline Groundwater flow $\left(\mathrm{mm} \mathrm{a}^{-1}\right)$ & 17.6 & 95.5 & $(-10)$ & 107.0 & (1) & 75.0 & $(-29)$ & 87.4 & $(-18)$ \\
\hline Surface runoff $\left(\mathrm{mm} \mathrm{a}^{-1}\right)$ & & 125.1 & & 136.5 & (1) & 145.9 & $(7)$ & 158.4 & (17) \\
\hline Act. Evapotranspiration $\left(\mathrm{mm} \mathrm{a}^{-1}\right)$ & 923.7 & 857.4 & $(-8)$ & 847.3 & $(-9)$ & 854.7 & $(-8)$ & 845.2 & $(-9)$ \\
\hline Sediment yield (ton $\mathrm{ha}^{-1} \mathrm{a}^{-1}$ ) & 0.4 & 0.5 & (13) & 0.5 & (15) & 0.6 & (45) & 0.6 & $(50)$ \\
\hline Organic $\mathrm{N}$ load $\left(\mathrm{kg} \mathrm{ha}^{-1} \mathrm{a}^{-1}\right)$ & & 0.7 & (1) & 0.8 & (9) & 1.0 & (36) & 1.0 & (46) \\
\hline \multicolumn{10}{|l|}{ Ouémé-Bonou $(49,256$ km²) } \\
\hline & & & & 1060.9 & $(-7)$ & & $(-9)$ & 1060.9 & $(-7)$ \\
\hline Water yield $\left(\mathrm{mm} \mathrm{a}^{-1}\right)$ & 224.6 & 193.3 & $(-14)$ & 215.8 & $(-4)$ & 201.6 & $(-10)$ & 223.3 & $(-1)$ \\
\hline Groundwater flow $\left(\mathrm{mm} \mathrm{a}^{-1}\right)$ & 147.6 & 111.9 & $(-24)$ & 124.1 & $(-16)$ & 102.6 & $(-30)$ & 113.8 & $(-23)$ \\
\hline Surface runoff $\left(\mathrm{mm} \mathrm{a}^{-1}\right)$ & & 81.4 & (6) & 91.7 & (19) & 99.0 & (29) & 109.6 & (42) \\
\hline Act. Evapotranspiration $\left(\mathrm{mm} \mathrm{a}^{-1}\right)$ & 794.8 & 740.4 & $(-7)$ & 734.6 & $(-8)$ & 733.0 & $(-8)$ & 728.3 & $(-8)$ \\
\hline Sediment yield (ton $\mathrm{ha}^{-1} \mathrm{a}^{-1}$ ) & 0.3 & 0.4 & (16) & 0.4 & (22) & 0.4 & (34) & 0.5 & (41) \\
\hline Organic $\mathrm{N}$ load $\left(\mathrm{kg} \mathrm{ha}^{-1} \mathrm{a}^{-1}\right)$ & 1.2 & 1.4 & (15) & 1.5 & (25) & 1.6 & (37) & 1.7 & (47) \\
\hline
\end{tabular}

Figure 14. Simulated trends under land use and climate scenarios (2025 to 2029). (a) Donga-Pont; (b) Ouémé-Bonou.
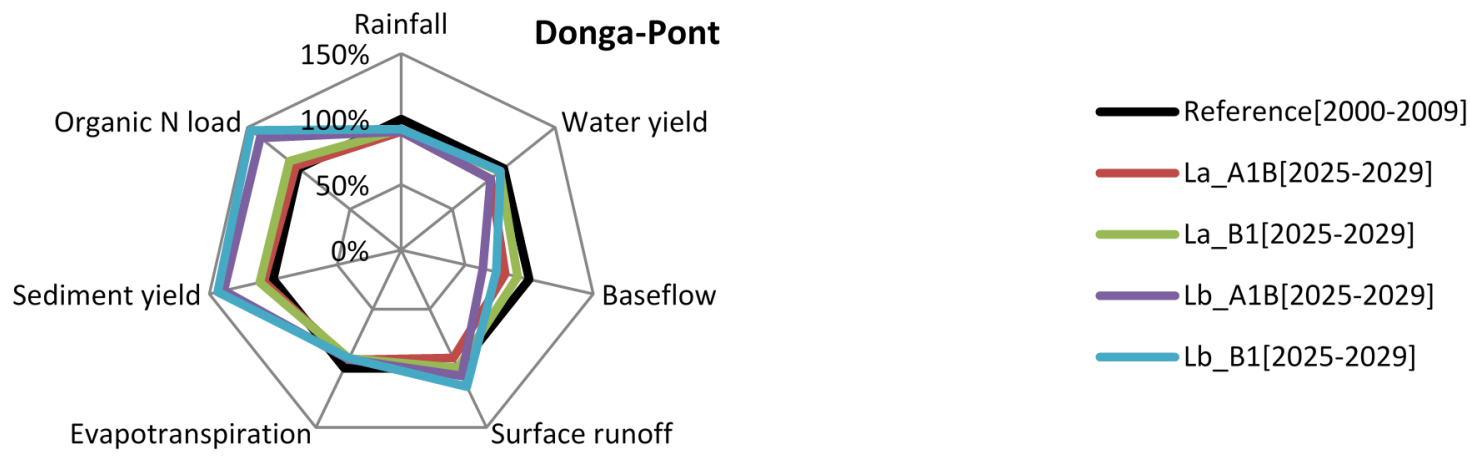

(a)

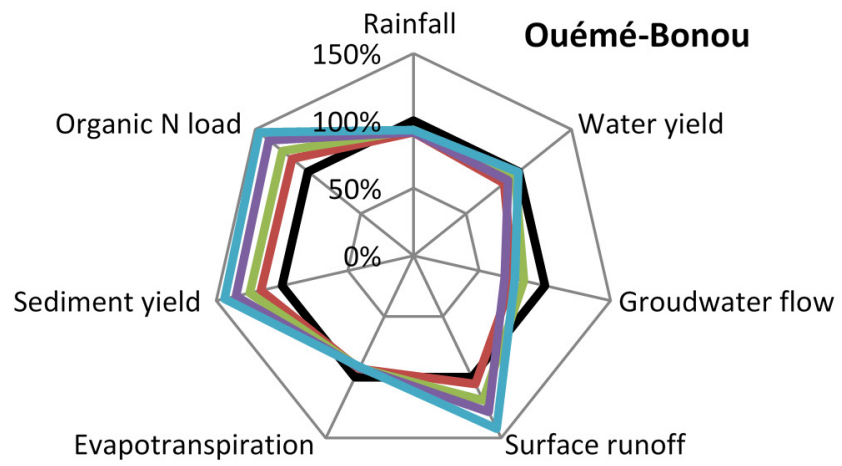

Reference[2000-2009]

$\longrightarrow$ La_A1B[2025-2029]

La_B1[2025-2029]

$\longrightarrow$ Lb A1B[2025-2029]

Lb_B1[2025-2029] 
In addition, the results suggest that variables such as surface runoff, groundwater flow, sediment and transported nutrients, mainly sensitive to land use change are significantly affected by scaledependent rate of agricultural lands, while variables such as water yield and evapotranspiration, mainly sensitive to climate change, have changed almost similarly at both scales. An application of the conceptual semi-distributed model UHP-HRU (Universal Hydrological Program-Hydrological Response Unit) in the same study area, using the physical-based model SIMULAT-H as benchmark [9], has led to a similar conclusion that water yield is more influenced by climate than land use, which more affects runoff components (surface runoff $v$ s. interflow and base flow). Results of scenario analysis from the same work [9] revealed that the amount of renewable water decreases during the period 2001-2049 in both climate IPCC SRES scenarios A1B and B1, which were also used in the present study.

Sediment yield was more important at the Donga-Pont catchment scale, ranging from 0.4 to 0.6 ton $\cdot \mathrm{ha}^{-1} \cdot \mathrm{a}^{-1}$ against 0.32 to $0.45 \mathrm{ton} \cdot \mathrm{ha}^{-1} \cdot \mathrm{a}^{-1}$ at the Ouémé-Bonou catchment scale. This may be explained by decreases of retrained eroded particles at large scale, due to sequestration in the inland valleys, which are important at large scales [9]. According to Vanmaercke et al. [66] and de Vente et al. [67], high erosion rates are often observed at the local scale, but sediment yield, which is the net transport out of the catchment, decreases with increasing size of the catchment. This is consistent with the results obtained.

The simulated organic nitrogen yield for the Ouémé-Bonou catchment (roughly 1.2 to 1.7 ton $\cdot \mathrm{ha}^{-1} \cdot \mathrm{a}^{-1}$ ) was almost twice the computed amount for the Donga-Pont catchment (roughly 0.5 to 1 ton $\cdot \mathrm{ha}^{-1} \cdot \mathrm{a}^{-1}$ ). This may be the consequence of the higher rate of agricultural lands in the Donga-Pont catchment, resulting in poorer topsoils in terms of humus and organic matters rates available.

Figure 15. Impacts of land use and climate change on Organic Nitrogen patterns in the Ouémé-Bonou catchment $\left(49,256 \mathrm{~km}^{2}\right)$.
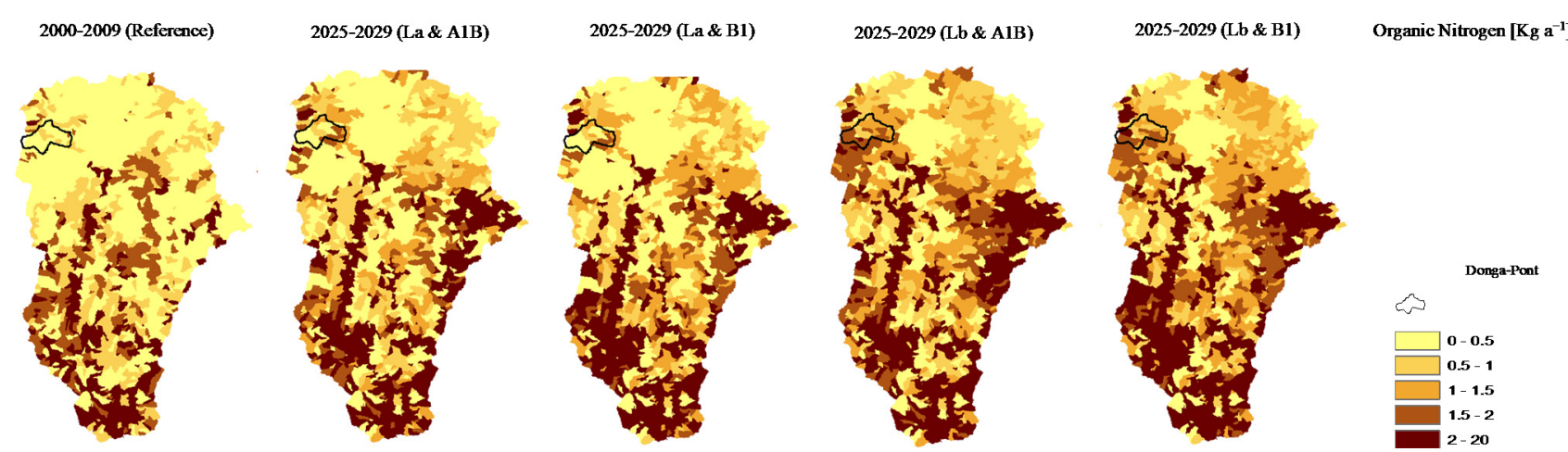

Figure 15 shows organic nitrogen load patterns for the combined scenarios (La \& A1B), (La \& B1), (Lb \& A1B) and (Lb \& B1) from 2000 to 2030 within the Ouémé-Bonou catchment. In accordance with the land use dynamic, the simulated pattern reflects higher and increasing degradation in the agricultural land. Surface runoff varies from 0 to $350 \mathrm{~mm} \cdot \mathrm{a}^{-1}$, sediment yield varies from 0 to 10 ton $\cdot \mathrm{ha}^{-1} \cdot \mathrm{a}^{-1}$, and lost soil organic nitrogen varies from 0 to $20 \mathrm{~kg} \cdot \mathrm{ha}^{-1} \cdot \mathrm{a}^{-1}$. Lost soil organic nitrogen shows higher dynamic and more threatened areas compared to sediment yield. This is completely consistent with the findings in section 3.3. As land use change was identified as the major 
driver of the ongoing land degradation, the scenario Lb (pessimistic, weak national economy, uncontrolled settlement and farmland development, 3.5\% population growth per year) must be avoided in order to exclude the effects simulated by the combinations (Lb \& A1B) and (Lb \& B1) for which larger threatened areas are shown in the figures.

In another study, SWAT was applied in the upper Ouémé catchment to evaluate the effects of climate change and land use change on soil erosion $[9,15]$. In their combined land use and climate scenarios, the soil erosion rates increases with a large variability within the study area, which shows the high impact of land use change. The study has concluded that in areas with a high potential of cropland expansion, future sediment yield will be driven by land use change and may therefore strongly increase. Conversely, in the areas with a low potential for cropland expansion and strong reductions in rainfall, future sediment yield may decrease.

These findings are consistent with the results presented in this study, which furthermore discussed aspects of soil organic nutrients.

\section{Conclusions}

Soil and water are essential natural resources, available in limited quantities, but are nowadays dangerously exposed to climate and land use change [33]. Balancing the future degradation requires a sufficient understanding of processes behind at different scales [33], a task that may not be possible without an overriding of difficulties related to data availability in a data-poor environment such as Benin.

In this work, a regionalization methodology is used to overcome two difficulties in model setup in the Ouémé catchment: parameter scale-effects and associated uncertainty issues for large scale model application [32] and the lack and non-accurateness of boundary condition data (e.g., stream water-sediment-nutrient measurements). The SWAT model was applied using scale dependent and regression-based parameter models to simulate climate and land use change impacts on water yield, sediment and nutrient loads in Benin at the meso and the regional scale $\left(49,256 \mathrm{~km}^{2}\right)$.

The results revealed significant and increasing impacts over years. Surface runoff, groundwater flow, sediment and organic nitrogen load were affected by land use change (as dominant effects) of $-8 \%$ to $+50 \%$, while water yield and evapotranspiration were affected by climate change (as dominant effects) of $-31 \%$ to $+2 \%$. These rates may be reached gradually over years and according to the scenario data used. It was found that variables such as sediment and soil nutrients, mainly sensitive to land use change were likely functions of scale-dependent cropland rates. Furthermore, higher sediment yields were associated with higher scale-dependent rate of croplands, while higher organic nitrogen loads were associated with higher scale-dependent rate of natural vegetations. Partly the effect of climate change (decrease in surface runoff) and land use change (increase in surface runoff) balance out, resulting in a complex reaction of the system to Global Change. These results are consistent with findings of Hiepe [15] and Speth et al. [9]. Nevertheless, it is clear that land use change acts on shorter time scales than climate change causing a higher impact of land use change in the next years.

This work is a significant contribution for supporting sustainable management strategies to drive stronger economic development that considers controlled settlements, controlled farmland extension, less pressures on natural vegetations, and sustainable farming system managements. The study reveals 
the relevancy and the efficiency of the modeling strategy used for bridging the data gap, since the results are consistent with previous findings within the study area. Future works should focus on the interaction between uncertainties associated with the scenario data and the model structural errors. This will help to clearly quantify the uncertainties in the simulated impacts which are not investigated in this work.

\section{Acknowledgments}

This work has been funded by the German Federal Ministry of Education and Research (BMBF) as part of the West African Science Service Center on Climate Change and Adapted Land Use (WASCAL) research program. Many thanks to our partners in Benin and all colleagues of the GLOWA-IMPETUS project-Global Wandel des Wasserkreislaufs-Integratives Management Projekt für einen effizienten und tragfähigen Umgang mit Süßwasser in Westafrika (Global Cange and the Hydrological Cycle - An integrated approach to the efficient management of scarce water resources in West Africa) who provided data and assistance. The first author thanks the German Academic Exchange Service for funding.

\section{Authors Contribution}

Aymar Y. Bossa, Euloge K. Agbossou and Bernd Diekkrüger designed the study, developed the methodology, and wrote the manuscript. Aymar Y. Bossa performed the field work, collected the data, and conducted the computer analysis while Euloge K. Agbossou and Bernd Diekkrüger supervised this part of the work.

\section{Conflicts of Interest}

The authors declare no conflict of interest.

\section{References}

1. United Nations Environment Programme (UNEP). Global Environment Outlook 4; Progress Press Ltd: Valleta, Malta, 2007.

2. Bossio, D.; Geheb, K.; Critchley, W. Managing water by managing land: Addressing land degradation to improve water productivity and rural livelihoods. Agric. Water Manag. 2010, 97, 536-542.

3. Oldeman, L.R. Guidelines for General Assessment of the Status of Human-induced Soil Degradation; Working Paper and Reprint 88/4; International Soil Reference and Information Centre: Wageningen, the Netherlands, 1991.

4. Scherr, S.J.; Yadav, S. Land degradation in the Developing World: Implications for Food, Agriculture, and the Environment to 2020; Food, Agriculture, and the Evironment Discussion Paper 14; International Food Policy Research Institute (IFPRI): Washington, DC, USA, 1996.

5. Lal, R. Soil Erosion in the Tropics. Principles \& Management; McGraw-Hill: New York, NY, USA, 1990. 
6. Giertz, S.; Diekkrüger, B.; Steup, G. Physically-based modeling of hydrological processes in a tropical headwater catchment in Benin (West Africa) - Process representation and multi-criteria validation. Hydrol. Earth Syst. Sci. 2006, 10, 829-847.

7. Laouina, A.; Coelho, C.; Ritsema, C.; Chaker, M.; Nafaa, R.; Fenjiro, I.; Antari, M.; Ferreira, A.; van Dijck, S. Dynamique de l'eau et gestion des terres dans le contexte du changement global, analyse agro-hydrologique dans le bassin du Bouregreg (Maroc). Sécheresse 2004, 15, 66-77. (In French)

8. Roose, E.; de Noni, G. Recherches sur l'érosion hydrique en Afrique: Revue et perspectives. Sci. Chang. Planétaires Sécheresse 2004, 15, 121-129. (In French)

9. Speth, P., Christoph, M., Diekkrüger, B., Eds. Impacts of Global Change on the Hydrological Cycle in West and Northwest Africa; Springer Publisher: Heidelberg, Germany, 2010.

10. Chen, L.; Zhu, A.X.; Qin, C. Identification of critical source areas of soil erosion on moderate fine spatial scale in Loess Plateau in China. African J. Agric. Res. 2012, 7, 2962-2970.

11. Ouyang, W.; Skidmore, A.K.; Hao, F.; Wang, T. Soil erosion dynamics response to landscape pattern. Sci. Total Environ. 2010, 408, 1358-1366.

12. United Nations World Water Assessment Programme. The Impact of Global Change on Erosion and Sediment Transport by Rivers: Current Processes and Future Challenges; the United Nations World Water Development Report 3; United Nation Educational: Paris, France, 2009.

13. Yang, D.; Kanae, S.; Oki, T.; Koike, T.; Musiake, K. Global potential soil erosion with reference to land use and climate changes. Hydrol. Process. 2003, 17, 2913-2928.

14. Lawal, O.; Gaiser, T.; Nuga, B. Estimation of potential soil losses on a regional scale: A case of Abomey-Bohicon Region, Benin Republic. Agric. J. 2007, 2, 1-8.

15. Hiepe, C. Soil Degradation by Water Erosion in a Sub-Humid West-African Catchment, a Modelling Approach Considering Land Use and Climate Change in Benin. Ph.D. Thesis, University of Bonn, Bonn, Germany, 19 December 2008.

16. Bossa, A.Y.; Diekkrüger, B.; Giertz, S.; Steup, G.; Sintondji, L.O.; Agbossou, E.K.; Hiepe, C. Modeling the effects of crop patterns and management practices on $\mathrm{N}$ and $\mathrm{P}$ loads to surface water and groundwater in a semi-humid catchment (West Africa). Agric. Water Manag. 2012, 115, 20-37.

17. Keyzer, M.A.; Sonneveld, B.G.J.S.; Pande, S. The Impact of Climate Change on Crop Production and Health in West Africa: An Assessment for the Oueme River Basin in Benin; Centre for World Food Studies: Amsterdam, the Netherlands, 2007.

18. Cornelissen, T.; Diekkrüger, B.; Giertz, S. A comparison of hydrological models for assessing the impact of land use and climate change on discharge in a tropical catchment. J. Hydrol. 2013, 498, 221-236.

19. Faramarzi, M.; Abbaspour, K.C.; Ashraf Vaghefi, S.; Farzaneh, M.R.; Zehnder, A.J.B.; Srinivasan, R.; Yang, H. Modeling impacts of climate change on freshwater availability in Africa. J. Hydrol. 2013, 480, 85-101.

20. Chaplot, V. Water and soil resources response to rising levels of atmospheric $\mathrm{CO}_{2}$ concentration and to changes in precipitation and air temperature. J. Hydrol. 2007, 337, 159-171.

21. Legesse, D.; Vallet-Coulomb, C.; Gasse, F. Hydrological response of a catchment to climate and land use changes in Tropical Africa: Case study South Central Ethiopia. J. Hydrol. 2003, 275, $67-85$. 
22. Li, K.Y.; Coe, M.T.; Ramankutty, N.; de Jong, R. Modeling the hydrological impact of land-use change in West Africa. J. Hydrol. 2007, 337, 258-268.

23. Neumann, R.; Jung, G.; Laux, P.; Kunstmann, H. Climate trends of temperature, precipitation and river discharge in the Volta Basin of West Africa. Int. J. River Basin Manag. 2007, 5, 37-41.

24. Mahe, G.; Paturel, J.; Servat, E.; Conway, D.; Dezetter, A. The impact of land use change on soil water holding capacity and river flow modelling in the Nakambe River, Burkina-Faso. J. Hydrol. 2005, 300, 33-43.

25. Ward, P.J.; van Balen, R.T.; Verstraeten, G.; Renssen, H.; Vandenberghe, J. The impact of land use and climate change on late Holocene and future suspended sediment yield of the Meuse catchment. Geomorphology 2009, 103, 389-400.

26. Oguntunde, P.G.; Abiodun, B.J. The impact of climate change on the Niger River Basin hydroclimatology, West Africa. Clim. Dyn. 2013, 40, 81-94.

27. Blöschl, G.; Sivapalan, M. Scale issues in hydrological modeling: A review. Hydrol. Proc. 1995, 9, 251-290.

28. Abbott, M.B.; Bathurst, J.C.; Cunge, J.A.; O’Connell, P.E.; Rasmussen, J. An introduction to the European Hydrological System-Systeme Hydrologique Europeen, "SHE", 2: Structure of a physically-based, distributed modeling system. J. Hydrol. 1986, 87, 61-77.

29. Sivapalan, M.; Viney, N.R. Large scale catchment modeling to predict the effects of land use and climate. Water J. Aust. Wat. Wastewat. Assoc. 1994, 21, 33-37.

30. Sivapalan, M.; Viney, N.R. Application of a nested catchment model for predicting the effects of changes in forest cover. In Forest Hydrology, Proceedings of International Symposium, Tokyo, Japan, October 1994; pp. 315-322.

31. Arnold, J.G.; Srinivasan, R.; Muttiah, R.S.; Williams, J.R. Large area hydrologic modeling and assessment part I: Model development. J. Am. Water Resour. Assoc. 1998, 34, 73-89.

32. FitzHugh, T.W.; Mackay, D.S. Impacts of input parameter spatial aggregation on an agricultural nonpoint source pollution model. J. Hydrol. 2000, 236, 35-53.

33. De Vente, J.; Poesen, J.; Verstraeten, G.; Govers, G.; Vanmaercke, M.; van Rompaey, A.; Arabkhedri, M.; Boix-Fayos, C. Predicting soil erosion and sediment yield at regional scales: Where do we stand? Earth Sci. Rev. 2013, 127, 16-29.

34. Thamm, H.P.; Judex, M.; Menz, G. Modeling of Land-Use and Land-Cover Change (LUCC) in Western Africa using remote sensing. Photogramm. Fernerkund. Geoinf. 2005, 3, 191-199.

35. Judex, M. Modellierung der Landnutzungsdynamik in Zentralbenin mit dem XULU-Framework. Ph.D. Thesis, University of Bonn, Bonn, Germany, 11 April 2008.

36. Paeth, H.; Born, K.; Podzun, R.; Jacob, D. Regional dynamic downscaling over West Africa: Model evaluation and comparison of wet and dry years. Meteorol. Zeit. 2005, 14, 349-367.

37. Regional Modelfor Integrated WaterManagement inTwinned River Basins (RIVERTWIN). Adapted and Integrated Model for the Ouémé River Basin, Final Report; Institute for Landscape Planning and Ecology: Stuttgart, Germany, 2007. 
38. Bossa, A.Y.; Diekkrüger, B. Estimating scale effects of catchment properties on modeling soil and water degradation. In Managing Resources of a Limited Planet: Pathways and Visions under Uncertainty, Proceedings of the International Environmental Modelling and Software Society (iEMSs), Sixth Biennial Meeting, Leipzig, Germany, 1-5 July 2012; Seppelt, R., Voinov, A.A., Lange, S., Bankamp, D., Eds.; International Environmental Modelling and Software Society: Leipzig, Germany, 2012; pp. 2974-2981.

39. Wright, E.P.; Burgess, W. The hydrogeology of crystalline basement in Africa. Geol. Soc. Spec. 1992, 66, 1-27.

40. Faure, P.; Volkoff, B. Some factors affecting regional differentiation of the soils in the Republic of Benin (West Africa). Catena 1998, 32, 281-306.

41. Junge, B. Die Böden des oberen Ouémé-Einzugsgebietes in Benin/Westafrika-Pedologie, Klassifizierung, Nutzung und Degradierung. Ph.D. Thesis, Institut für Bodenkunde, Bonn, Germany, 23 July 2004.

42. Soil Conservation Service Engineering Division. Urban Hydrology for Small Watersheds; Technical Release 55; U.S. Department of Agriculture: Washington, DC, USA, 1986.

43. Sloan, P.G.; Moore, I.D. Modelling subsurface stormflow on steeply sloping forested watersheds. Water Resour. Res. 1984, 20, 1815-1822.

44. Williams, J.R. Sediment-yield prediction with universal equation using runoff energy factor. In Present and Prospective Technology for Predicting Sediment Yield and Sources. Proceedings of the sediment yield workshop, USDA Sedimentation Lab, Oxford, MS, USA, 28-30 November 1972; U.S. Department of Agriculture: Washington, DC, USA, 1975; pp. 244-252.

45. McElroy, A.D.; Chiu, S.Y.; Nebgen, J.W.; Aleti, A.; Bennett, F.W. Loading Functions for Assessment of Water Pollution from Nonpoint Sources; EPA document EPA 600/2-76-151; Midwest Research Institute: Kansas City, KS, USA, 1976.

46. Williams, J.R.; Hann, R.W. Optimal Operation of Large Agricultural Watersheds with Water Quality Constraints; Tech. Rep. No. 96; Texas Water Resources Institute: Temple, TX, USA, 1978.

47. Ritchie, J.T. A model for predicting evaporation from a row crop with incomplete cover. Water Resour. Res. 1972, 8, 1204-1213.

48. Christoph, M.; Fink, A.; Diekkrüger, B.; Giertz, S.; Reichert, B.; Speth, P. IMPETUS: Implementing HELP in the Upper Ouémé Basin. Water $S A$ 2008, 34, 481-490.

49. Igué, A.M. Soil Information System for the Oueme Basin; Institut National de la Recherche Agricole du Bénin (INRAB): Cotonou, Benin, 2005.

50. Bossa, A.Y.; Diekkrüger, B.; Igué, A.M.; Gaiser, T. Analyzing the effects of different soil databases on modeling of hydrological processes and sediment yield in Benin (West Africa). Geoderma 2012, 173-174, 61-74.

51. Abbaspour, K.C. SWAT Calibration and Uncertainty Programs-A User Manual; Department of Systems Analysis, Integrated Assessment and Modeling (SIAM), Eawag, Swiss Federal Institute of Aquatic Science and Technology: Duebendorf, Switzerland, 2008.

52. Lam, Q.D.; Schmalz, B.; Fohrer, N. Modelling point and diffuse source pollution of nitrate in a rural lowland catchment using the SWAT model. Agric. Water Manag. 2010, 97, 317-325. 
53. Food and Agriculture Organization (FAO). Control of Water Pollution from Agriculture-FAO Irrigation and Drainage Paper 55; Food and Agriculture Organization of the United Nations Rome: Rome, Italy, 1996.

54. Paeth, H.; Born, K.; Girmes, R.; Podzun, R.; Jacob, D. Regional climate change in tropical Africa under greenhouse forcing and land-use changes. J. Clim. 2009, 22, 114-132.

55. Patricola, C.M.; Cook, K.H. Northern African climate at the end of the twenty-first century: An integrated application of regional and global climate models. Clim. Dyn. 2010, 37, 1165-1188.

56. Druyan, L.M. Studies of 21 st-century precipitation trends over West Africa. Int. J. Climatol. 2011, 31, 1415-1424.

57. Held, I.M.; Delworth, T.L.; Lu, J.; Findell, K.L.; Knutson, T.R. Simulation of Sahel drought in the twentieth- and twenty-first centuries. Proc. Natl. Acad. Sci. USA 2005, 102, 17891-17896.

58. Kamga, A.F.; Jenkins, G.S.; Gaye, A.T.; Garba, A.; Sarr, A.; Adedoyin, A. Evaluating the National Center for Atmospheric Research climate system model over West Africa: Present-day and the 21st century A1 scenario. J. Geophys. Res. 2005, 110, doi:10.1029/2004JD004689.

59. Hoerling, M.; Hurrell, J.; Eischeid, J.; Phillips, A. Detection and attribution of 20th century Northern and Southern African rainfall change. J. Clim. 2006, 19, 3989-4008.

60. Cook, K.H.; Vizy, E.K. Coupled model simulations of the West African monsoon system: Twentieth- and twenty-first-century simulations. J. Clim. 2006, 19, 3681-3703.

61. Biasutti, M.; Held, I.M.; Sobel, A.H.; Giannini, A. SST forcings and Sahel rainfall variability in simulations of the twentieth and twenty- first centuries. J. Clim. 2008, 21, 3471-3486.

62. Maraun, D.; Wetterhall, F.; Ireson, A.M.; Chandler, R.E.; Kendon, E.J.; Widmann, M.; Brienen, S.; Rust, H.W.; Sauter, T.; Themeß1, M.; et al. Precipitation downscaling under climate change: Recent developments to bridge the gap between dynamical models and the end user. Rev. Geophys. 2009, 48, doi:10.1029/2009RG000314.

63. Paeth, H. Key factors in African climate change evaluated by a regional climate model. Erdkunde 2004, 58, 290-315.

64. Igue, A.M.; Houndagba, C.J.; Gaiser, T.; Stahr, K. Land use/cover map and its accuracy in the Oueme Basin of Benin (West Africa). Int. J. Agri. Sci. 2012, 2, 174-184.

65. Götzinger, J. Distributed Conceptual Hydrological Modeling-Simulation of Climate, Land Use Change Impact and Uncertainty Analysis. Ph.D. Thesis, University of Stuttgart, Stuttgart, Germany, 19 July 2007.

66. Vanmaercke, M.; Poesen, J.; Verstraeten, G.; de Vente, J.; Ocakoglu, F. Sediment yield in Europe: Spatial patterns and scale dependency. Geomorphology 2011, 130, 142-161.

67. De Vente, J.; Poesen, J.; Verstraeten, G. The application of semi-quantitative methods and reservoir sedimentation rates for the prediction of basin sediment yield in Spain. J. Hydrol. 2005, 305, 63-86.

(C) 2014 by the authors; licensee MDPI, Basel, Switzerland. This article is an open access article distributed under the terms and conditions of the Creative Commons Attribution license (http://creativecommons.org/licenses/by/4.0/). 